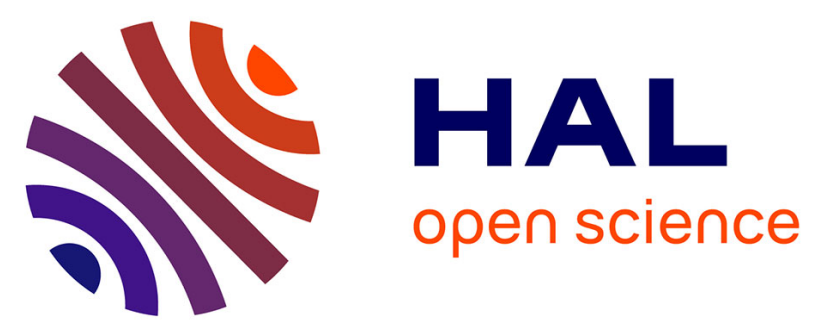

\title{
Nasal compartmentalization in Kogiidae (Cetacea, Physeteroidea): insights from a new late Miocene dwarf sperm whale from the Pisco Formation
}

Aldo Benites-palomino, Jorge Vélez-juarbe, Alberto Collareta, Diana Ochoa, Alí Altamirano, Matthieu Carré, Manuel Laime, Mario Urbina, Rodolfo Salas-gismondi

\section{To cite this version:}

Aldo Benites-palomino, Jorge Vélez-juarbe, Alberto Collareta, Diana Ochoa, Alí Altamirano, et al.. Nasal compartmentalization in Kogiidae (Cetacea, Physeteroidea): insights from a new late Miocene dwarf sperm whale from the Pisco Formation. Papers in Palaeontology, 2021, 7 (3), pp.1507-1524. 10.1002/spp2.1351 . hal-03336072

\section{HAL Id: hal-03336072 https://hal.science/hal-03336072}

Submitted on 29 Nov 2021

HAL is a multi-disciplinary open access archive for the deposit and dissemination of scientific research documents, whether they are published or not. The documents may come from teaching and research institutions in France or abroad, or from public or private research centers.
L'archive ouverte pluridisciplinaire HAL, est destinée au dépôt et à la diffusion de documents scientifiques de niveau recherche, publiés ou non, émanant des établissements d'enseignement et de recherche français ou étrangers, des laboratoires publics ou privés.

\section{(c)(1)}

Distributed under a Creative Commons Attribution| 4.0 International License 


\title{
NASAL COMPARTMENTALIZATION IN KOGIIDAE (CETACEA, PHYSETEROIDEA): INSIGHTS FROM A NEW LATE MIOCENE DWARF SPERM WHALE FROM THE PISCO FORMATION
}

\author{
by ALDO BENITES-PALOMINO ${ }^{1,2,3}$ D, JORGE VÉLEZ-JUARBE ${ }^{4,5}$, \\ ALBERTO COLLARETA ${ }^{6}$, DIANA OCHOA ${ }^{7}$, Ali ALTAMIRANO ${ }^{3}$, \\ MATTHIEU CARRÉ ${ }^{7,8}$, MANUEL J. LAIME ${ }^{3}$, MARIO URBINA $^{3}$ and \\ RODOLFO SALAS-GISMONDI ${ }^{3,7}$ \\ ${ }^{1}$ Center for Tropical Paleoecology \& Archaeology, Smithsonian Tropical Research Institute, Balboa, Ancón 0843-03092, Panama; aldomar1955@gmail.com \\ ${ }^{2}$ Paläontologisches Institut und Museum, Universität Zürich, Karl Schmid Strasse 4, 8006, Zürich, Switzerland \\ ${ }^{3}$ Departamento de Paleontología de Vertebrados, Museo de Historia Natural - Universidad Nacional Mayor de San Marcos, Avenida Arenales 1256, Lima, 11, \\ Peru; eraexcusa@yahoo.es, belonodelphis@gmail.com, mariourbina01@hotmail.com \\ ${ }^{4}$ Department of Mammalogy, Natural History Museum of Los Angeles County, 900 Exposition Blvd, Los Angeles, CA 90007, USA; jvelezjuar@nhm.org \\ ${ }^{5}$ Department of Paleobiology, National Museum of Natural History, Smithsonian Institution, Washington, DC 20560, USA \\ ${ }^{6}$ Dipartimento di Scienze della Terra, Università di Pisa, via Santa Maria 53, 56126, Pisa, Italy; alberto.collareta@unipi.iti \\ ${ }^{7}$ BioGeoCiencias Lab, Facultad de Ciencias y Filosofía/CIDIS, Universidad Peruana Cayetano Heredia, Lima, Peru; rodolfo.salas@upch.pe; diana.ochoa@upch.pe \\ ${ }^{8}$ LOCEAN Laboratory, CNRS-IRD-MNHN-Sorbonne Universités (UPMC), 75005, Paris, France; matthieu.carre@loceanpsl.upmc.fr
}

Typescript received 24 July 2020; accepted in revised form 5 November 2020

\begin{abstract}
Facial compartmentalization in the skull of extant pygmy whales (Kogiidae) is a unique feature among cetaceans that allows for the housing of a wide array of organs responsible for echolocation. Recent fossil findings indicate a remarkable disparity of the facial bone organization in Miocene kogiids, but the significance of such a rearrangement for the evolution of the clade has been barely explored. Here we describe Kogia danomurai sp. nov., a late Miocene (c. $5.8 \mathrm{Ma}$ ) taxon from the Pisco Formation (Peru), based on a partially preserved skull with a new facial bone pattern. Phylogenetic analysis recovers $K$. danomurai as the most basal representative of the extant genus Kogia, displaying a combination of derived (incipiently developed and excavated sagittal facial crest) and plesiomorphic features (high position of the temporal fossa, and antorbital notch not transformed into a narrow slit). Furthermore, when
\end{abstract}

compared with the extant Kogia, the facial patterning found in $K$. danomurai indicates differential development among the facial organs, implying different capabilities of sound production relative to extant Kogia spp. Different facial bone patterns are particularly notable within the multi-species kogiid assemblage of the Pisco Formation, which suggests causal connections between different patterns and feeding ecologies (e.g. nekton piscivory and benthic foraging). At c. $5.8 \mathrm{Ma}, K$. danomurai was part of a cetacean community composed of clades typical of the late Miocene, and of other early representatives of extant taxa, a mixture probably representing an initial shift of the coastal faunas toward the ecosystem dynamics of the present-day south-eastern Pacific.

Key words: Messinian, marine mammals, Kogiinae, Pisco Formation, Peru, south-eastern Pacific.
Pygmy (Kogia sima (Owen, 1866)) and dwarf (K. breviceps (Blainville, 1838)) sperm whales (Physeteroidea, Kogiidae) are a group of highly elusive cetaceans that inhabit tropical and temperate ocean regions across the globe, mostly foraging for squids using suction feeding (Bloodworth \& Odell 2008). These animals are relatives of the great sperm whale, the physeterid Physeter macrocephalus Linnaeus, 1758, from which they differ by the smaller body size and presence of highly derived facial organs (Thornton et al. 2015; Velez-Juarbe et al. 2015). Both Kogia and Physeter and their fossil relatives display a high degree of cranial asymmetry (Coombs et al. 2020), with a dorsal excavation known as the supracranial basin, which houses their hypertrophied nasal organs. However, kogiids exhibit a sagittal facial crest that medially splits the supracranial basin into two, thus producing several regions for the attachment of the facial muscles, nasal complex organs, and other soft-tissue structures (Clarke 
2003; Thornton et al. 2015). These organs and soft-tissue structures are homologous to regions present in the melon of other odontocetes (Norris \& Harvey 1972); nevertheless, in Kogia, these are independent structures that both fulfil a specific function and occupy a specific region of the forehead. Such a patterning of the facial organs is herein referred to as compartmentalization.

Molecular estimates suggest that kogiids diverged from the rest of the physeteroids during the late Oligocene (McGowen et al. 2009, 2019; Geisler et al. 2011); however, the large majority of fossil kogiids come from late Miocene - early Pliocene deposits across the world, and as such, they highlight an outstanding diversification during this time span (Collareta et al. 2019, 2020). The Pisco Formation exposed in the coastal desert of southern Peru $\left(13^{\circ}-16^{\circ} \mathrm{S}\right)$ has been recognized as a major diversification hotspot of sperm whales. In fact, four species of extinct kogiids have been described so far from the Pisco strata, namely: Scaphokogia cochlearis Muizon, 1988; Koristocetus pescei Collareta et al., 2017; Scaphokogia totajpe BenitesPalomino et al., 2020a; and Platyscaphokogia landinii Collareta et al., 2020. Such a broad taxonomic diversity during the late Miocene and Pliocene was not restricted to kogiids, but also applies to other physeteroids (Lambert et al., 2016). 'Macroraptorial' sperm whales also attained a great diversity, as highlighted by the presence of three different species of the genus Acrophyseter, plus the large Livyatan melvillei Lambert et al., 2010 (Lambert et al. 2008, 2010, 2016). Here, we describe a new kogiid taxon from upper Miocene strata of the Pisco Formation exposed at the Sacaco locality and perform a comprehensive analysis of the heterogeneous patterns of variation of the craniofacial region in kogiids.

\section{GEOLOGICAL SETTING}

The Pisco Formation is a Neogene marine sedimentary unit, cropping out along the southern coast of Peru, which is known as one of the most remarkable Cenozoic marine fossil Lagerstätten worldwide due to the abundance, diversity, and excellent state of preservation of the fossil vertebrates therein contained (Esperante et al. 2008; Lambert et al. 2015; Gioncada et al. 2016). The Pisco Formation consists of conglomerates, sandstones, diatomaceous siltstones, tephra layers, and nodular dolomitic beds that represent a shallow-marine environment characterized by high ocean primary productivity and strong upwelling conditions (Dunbar et al. 1990; DeVries 1998; Di Celma et al. 2017, 2018). The southernmost deposits of the Pisco Formation occur in the Sacaco area $\left(15^{\circ}-16^{\circ}\right.$ S; Fig. 1) of the Sacaco basin, where five fossil vertebrate-bearing localities have been recognized since the 1980s, namely El
Jahuay, Aguada de Lomas, Montemar, Sud Sacaco (west), and the eponymous Sacaco (Muizon 1984; Muizon \& DeVries 1985; Ehret et al. 2012).

The holotype of $K$. danomurai sp. nov. described herein was found and collected in 2019 at the Sacaco locality from strata referred to the 'Sacaco vertebrate level' (= SAO) of Muizon (1984) and Muizon \& DeVries (1985) (Figs 1, 2). The rock record from this locality consists of metre-scale packages of massive to parallel-laminated yellowish sandstones (Fig. 2). These sandstones are mostly fine to medium grained, poorly cemented, and display variable contents of silt and shell fragments. Sandstone packages alternate with shell banks of various thicknesses that mainly contain remains of Dosinia sp. and Anadara sp. (DeVries \& Frassineti 2003). Three distinct volcanic ash layers, from which radiometric dates have been obtained (Muizon \& Bellon 1980; DO unpub. data), also occur at the base of this succession. The depositional environment of the SAO strata has been interpreted as a shallow sea adjacent to a rugged coastline that formed protected bays, peninsulas, archipelagos, and lagoons (Marocco \& Muizon 1988).

The age of the SAO deposits has been a subject of debate over the last decades. Muizon \& Bellon (1980) proposed an age of $3.9 \pm 0.2 \mathrm{Ma}$ based on the $\mathrm{K}-\mathrm{Ar}$ radiometric dating of one volcanic ash layer. Later, Ehret et al. (2012) evaluated the age of the SAO beds at $5.89 \mathrm{Ma}$ based on strontium isotope stratigraphy using mollusc shells. The latter age estimate is, however, in agreement with an unpublished result $(5.75 \pm 0.05 \mathrm{Ma})$ obtained from an Ar-Ar radiometric dating of biotite crystals from a nearby tephra horizon (see details in Ehret et al. 2012). As consequence of this, there was no consensus on whether the SAO beds were latest Miocene (5.7$5.8 \mathrm{Ma})$ or Pliocene $(3.9 \pm 0.2 \mathrm{Ma})$ in age. However, a recent reassessment of the age through $\mathrm{U}-\mathrm{Pb}$ radiometric dating of two volcanic ashes, including the ash layer analysed by Muizon \& Bellon (1980), yielded reliable and consistent latest Miocene ages $(5.74 \pm 0.056$ and $5.848 \pm 0.031 \mathrm{Ma}$; Fig. 2 ; DO unpub. data), similar to the one proposed by Ehret et al. (2012). We thus regard the geological age of the SAO deposits as latest Miocene (i.e. late Messinian; 5.8-5.7 Ma).

\section{MATERIAL AND METHOD}

Specimens analysed for comparison

In addition to MUSM 3888, we have directly examined for comparison the following fossil and extant Physeteroidea: Acrophyseter deinodon Lambert et al., 2008 (MNHN SAS 1626); Acrophyseter robustus Lambert et al., 

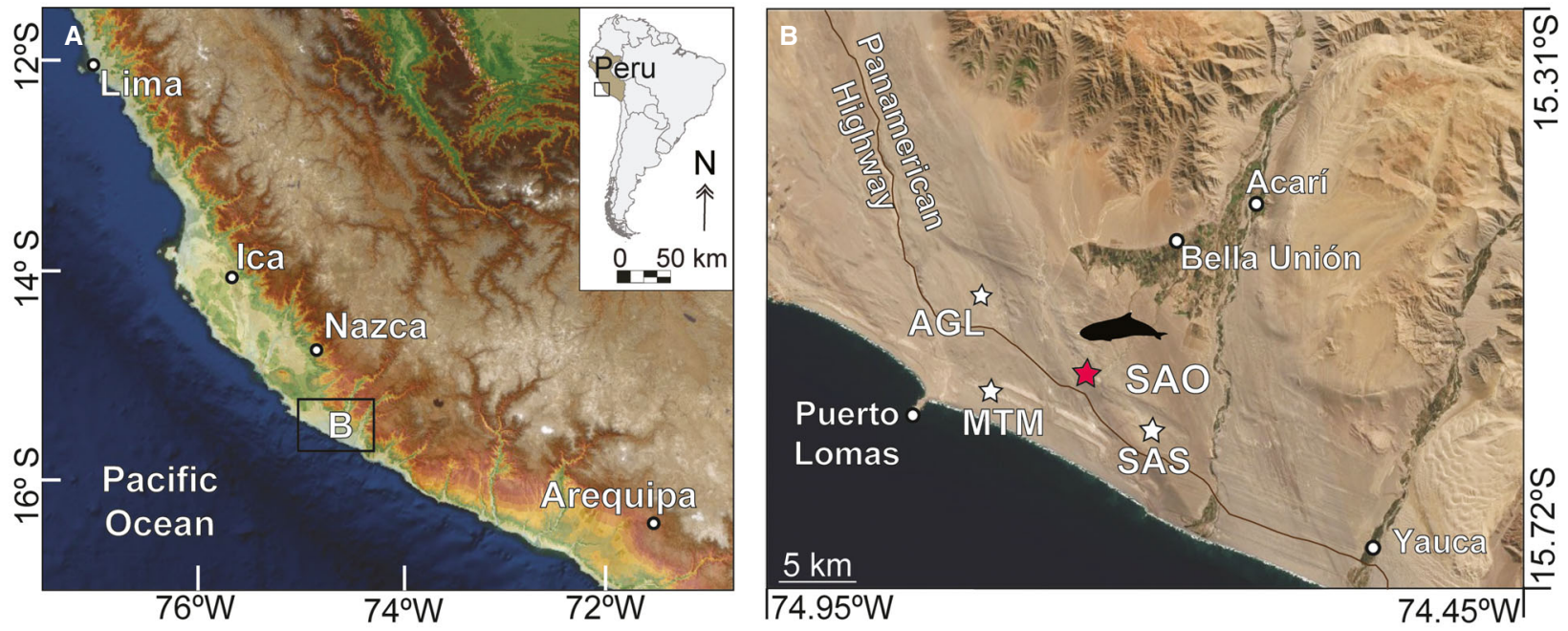

FIG. 1. A, relief map of the southern coast of Peru, showing the location of the Sacaco area (rectangle). B, close-up of the Sacaco area, showing the location of the type locality (SAO, red star) of Kogia danomurai sp. nov., along with other vertebrate-bearing localities. Abbreviations: AGL, Aguada de Lomas; MTM, Montemar; SAO, Sacaco; SAS, South Sacaco. Map source: 30 arc-second digital elevation model of South America (Data Basin Dataset), US Geological Survey's Center for Earth Resources Observation and Science (EROS).

2016 (MUSM 13399); Acrophyseter sp. (MUSM 2182); Aprixokogia kelloggi Whitmore \& Kaltenbach, 2008 (USNM 187015); Aulophyseter morricei Kellogg, 1927 (USNM 11230, LACM 50626, LACM 154100); Diaphorocetus poucheti (Moreno, 1892) (MLP 5-6); Kogia breviceps (LACM 27082, LACM 95745, UF 13562, UF 14213, UF 14214, UF 15732, UF 18702, UF 18704, UF 19128, UF 25545, USNM 504902, USNM 504921); Kogia pusilla (Pilleri, 1987) (IGF 1540V); Kogia sima (LACM 47142, LACM 95817; MSNC 3450; MUSNAF Mam410; UF 18705, UF 18706, UF 24629, UF 25573, UF 25575-25578); Koristocetus pescei (MUSM 888); Livyatan melvillei (MUSM 1676); Nanokogia isthmia Velez-Juarbe et al., 2015 (UF 273554, UF 280000); Platyscaphokogia landinii (MUSM 3291, 3405); Praekogia cedrosensis Barnes, 1973 (UCMP 315299); Pliokogia appeninica Collareta et al., 2019 (MSNUP I-17603); Physeter macrocephalus (MSNUP I-266); Scaphokogia cochlearis (MHN PPI 229, MUSM 978, MUSM 1998); Scaphokogia totajpe (MUSM 973); Scaphokogia sp. (MUSM 972); Thalassocetus antwerpiensis (IRSNB M.525).

\section{Anatomical terminology}

The morphological description of the holotype skull was based on Mead \& Fordyce (2009), with modifications to the facial region of Kogiidae (soft-tissue organs and other cranial features) by Thornton et al. (2015) and VelezJuarbe et al. (2015). Muscular and other soft tissues nomenclature follow Schulte \& Forest Smith (1918).
Institutional abbreviations. IGF, Istituto di Geologia di Firenze (= Museo di Storia Naturale, Sezione di Geologia e Paleontologia, Università degli Studi di Firenze), Italy; IRSNB, Institut Royal des Sciences naturelles de Belgique, Brussels, Belgium; LACM, Departments of Vertebrate Paleontology and Mammalogy, Natural History Museum of Los Angeles County, Los Angeles, California, USA; MLP, Museo de La Plata, Buenos Aires, Argentina; MNHN, Muséum national d'Histoire naturelle, Paris, France; MSNC, Museo Civico di Storia Naturale, Comiso, Italy; MSNUP, Museo di Storia Naturale dell'Università di Pisa, Italy; MUSM, Departamento de Paleontología de Vertebrados, Museo de Historia Natural de la Universidad Nacional Mayor de San Marcos, Lima, Peru; MUSNAF, Museo di Storia Naturale dell'Accademia dei Fisiocritici, Sienna, Italy; UCMP, University of California Museum of Palaeontology, Berkeley, California, USA; UF, Mammalogy Collection, Florida Museum of Natural History, Gainesville, Florida, USA; USNM, Department of Paleobiology, National Museum of Natural History, Smithsonian Institution, Washington DC, USA.

Additional abbreviation. char., character state; as described and numbered by Lambert et al. (2016), with modifications from prior and subsequent works (Boersma \& Pyenson 2015; VelezJuarbe et al. 2015; Collareta et al. 2017); e.g. 'char. 6[1]' refers to state 1 of character 6 .

\section{SYSTEMATIC PALAEONTOLOGY}

CETACEA Brisson, 1762

ODONTOCETI Flower, 1867

PAN-PHYSETEROIDEA Velez-Juarbe et al., 2015 


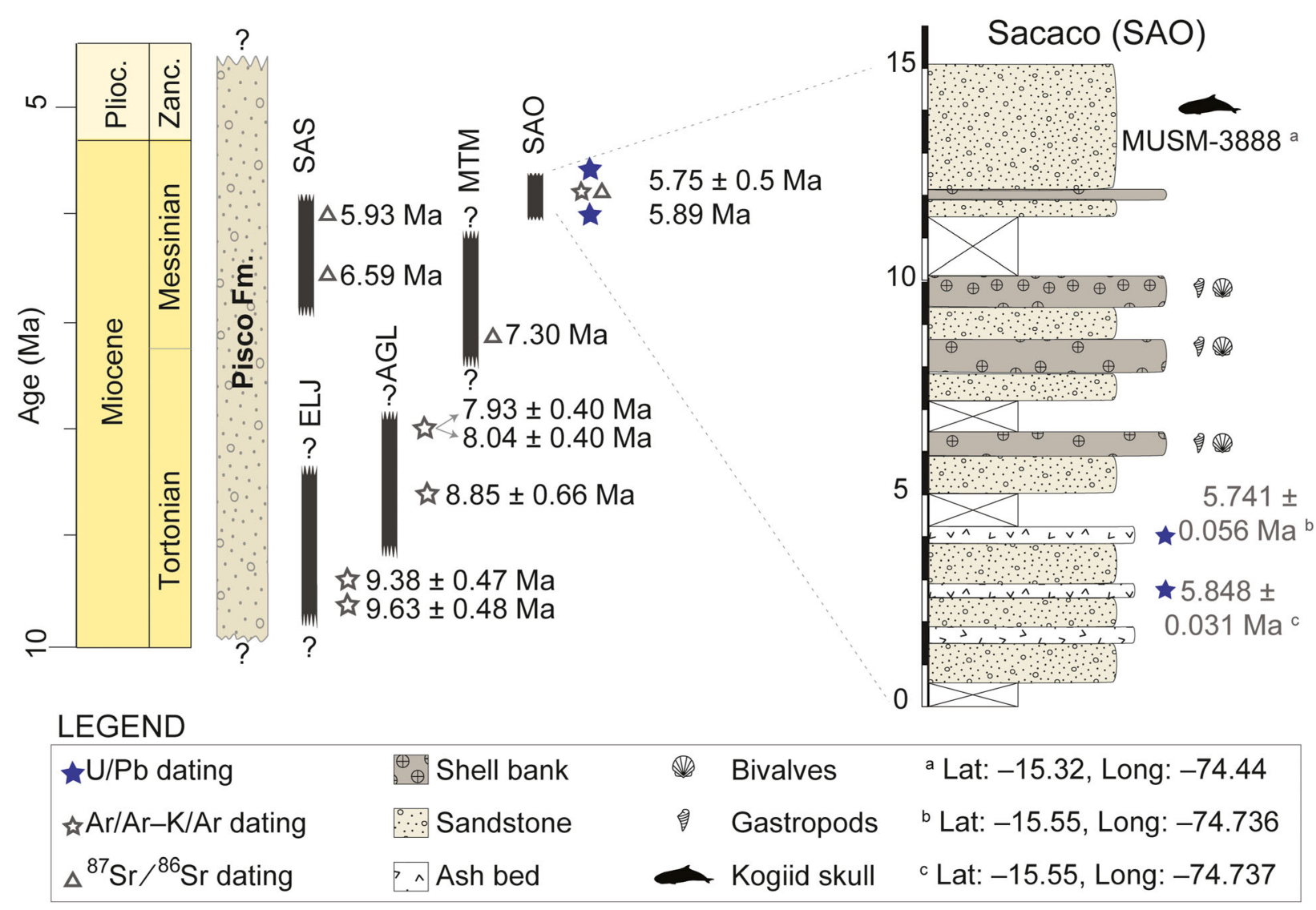

FIG. 2. Schematic representation of the main localities from the Pisco Formation in the Sacaco area: AGL, Aguada de Lomas; ELJ, El Jahuay-Altogrande; MTM, Montemar; SAO, Sacaco; SAS, South Sacaco. New and pre-existing radiometric (stars) and strontium ratio (triangles) age constraints are also indicated for each locality. To the right, stratigraphic column for the locality where MUSM 3888 was found, showing the position of U-Pb radiometric dates. Age data from Ehret et al. (2012), Muizon \& Bellon (1980) and DO (unpub. data). Abbreviations: Plio., Pliocene; Zanc., Zanclean.

\section{PHYSETEROIDEA Gray, 1821 KOGIIDAE Gill, 1871 KOGIINAE Gill, 1871 KOGIA Gray, 1846}

Type species. Physeter breviceps Blainville, 1838

Included species. Kogia breviceps; K. sima; K. pusilla; K. danomurai sp. nov.

Emended diagnosis. Small to medium-sized physeteroids. In extant species, sexual maturity is observed for individuals over $1.9 \mathrm{~m}$ in total body length, whereas the maximum adult length is c. $3.5 \mathrm{~m}$ (Bloodworth \& Odell 2008). Based on allometric equations for reconstructing the body size (Pyenson \& Sponberg 2011), the length of the fossil species would have been similar (see Differential Diagnosis of $K$. danomurai below). The skull of Kogia displays a triangular outline, being wider in the facial region and narrowing towards the apex of the rostrum (condition unknown in $K$. danomurai). This blunt rostrum condition is referred to as amblygnathy (Werth 2006), being highly derived in both the extant species. The rostrum is flat to concave (as highlighted by the rostrum fragment of $K$. danomurai), thus indicating that the supracranial basin extended anteriorly over the dorsal rostral surface (char. 3[2]). The mesorostral groove is open along the rostrum (unknown in $K$. danomurai). Ventrally, the maxillae lack functional, well-individualized dental alveoli (char. 6[1]; unknown in $K$. danomurai). The antorbital notch enters the supracranial basin, extending posteriorly towards the posterior edge of the right bony naris. The external bony nares are located at (or slightly posterior to) the level of the preorbital process. The sagittal facial crest extends posteriorly from the external bony nares and reaches the occipital crest, thus dividing the supracranial basin into a left and a right maxillary fossa and hosting a medially displaced premaxillary fossa. The maxillary crests are moderately to fairly robust and project dorsally above the level of the supracranial basin. In dorsal view, the supraorbital process extends laterally beyond the lateral walls of the cranial vault, a condition enhanced by the relatively low position of the postorbital process (only known in extant Kogia spp.) The relative size of the maxillary fossae varies, from being moderately asymmetrical (as in K. danomurai) to overall similar in size to each other (as in extant $K$. sima and K. breviceps). Posteriorly, 
the occipital shield is flat and forms an angle of $c .90^{\circ}$ with the main body axis (char.30[2]). The surface of the occipital shield is flat to slightly convex. Laterally, the temporal fossa is shallow and proportionally small when compared with the rest of the skull, being notoriously reduced in K. sima.

Chronostratigraphic distribution. Kogia sima and K. breviceps are extant species. The holotype skull of $K$. danomurai sp. nov. was found in the uppermost Miocene Sacaco (SAO, 5.84-5.74 Ma) vertebrate level (as defined by Muizon \& DeVries 1985), Sacaco locality, Sacaco basin. The holotype skull of Kogia pusilla was recovered from the Monte Voltraio locality (Pisa, Italy) and it has been regarded as late Pliocene (3-2.6 Ma; Bianucci et al. $1998)$ in age. Isolated periotics referred to Kogia have been described from the lower Pliocene (c. 4.8-3.1 Ma) Yorktown Formation of North Carolina (Vélez-Juarbe et al. 2016), as well as from the Pliocene of Italy (Pilleri 1987; Bianucci 1996). Additional fragmentary remains have been attributed to Kogia by previous authors, however, given that these reports were based on isolated teeth (e.g. Kogia prisca Matsumoto, 1926), their assignment to this living genus (and even to the family Kogiidae) is largely unsupported (Barnes 1973). Therefore, we constrain the presence of the genus Kogia from the latest Miocene (5.84 Ma) to the present day.

\section{Kogia danomurai sp. nov. Figure 3}

\section{LSID. urn:lsid:zoobank.org:act:1F6E4C83-FB4D-41BB-B8E0- 4D2DFA3F162D}

Derivation of name. The specific name honours the Peruvian science professor Dan Omura, in recognition of his contribution to national vertebrate palaeontology, as member of both the Department of Vertebrate Palaeontology of the Natural History Museum of the Universidad Nacional Mayor de San Marcos (UNMSM, Lima) and the Peruvian School La Union.

Holotype. MUSM 3888, a partial cranium, preserving the facial and dorsolateral regions of the cranial vault, but lacking most of the rostrum and basicranium. Collected by Mario Urbina, Rodolfo Salas-Gismondi, Diana Ochoa and Ali Altamirano in 2019.

Differential diagnosis. Small physeteroid with an estimated total body length of $c .232 \mathrm{~cm}$ (based on the body size equation proposed by Pyenson \& Sponberg 2011 for Physeteroidea). Among known kogiids, it is recognized by the following combination of characters: rostrum surface slightly concave, as suggested by the rostral fragment with the supracranial basin of the skull extending onto the dorsal surface of the rostrum (char. 3[2]; shared with Physeter macrocephalus, Aprixokogia and Kogia spp.); antorbital notches transversely widened, but not transformed into narrow slits as in most kogiids (char. 9[1], shared with Aprixokogia and Praekogia); antorbital processes slightly thickened, a condition fully developed only in extant Kogia spp.; one large maxillary foramen located slightly anterolateral to the right bony naris (char. 11[3]); maxillary crests transversely thickened and high, greatly extending above the level of the supracranial basin; supracranial basin moderately excavated, resembling Praekogia, Pliokogia and Nanokogia, and contrasting with the deeper basin present in Scaphokogia and modern Kogia spp.; nuchal crest presenting a W-shaped outline in dorsal view (condition shared with extant Kogia spp., unknown in Pliokogia and Koristocetus); relatively short projection of the lacrimojugal complex between the frontal and maxilla (char. 23[0], shared with Nanokogia and S. totajpe); and temporal fossa located in a relatively high position, its top being observed just below the dorsal level of the maxillary crests (char. 44[0], shared with Scaphokogia spp.). K. danomurai can be further distinguished from other kogiids by presenting: a blunt outline of the premaxillary processes in the dorsal view of the skull; and a sagittally located premaxillary fossa that is shallowly excavated and located below the average level of the supracranial basin, being well-delimited leftwards but only vaguely delimited rightwards.

Horizon and age. The holotype cranium of $K$. danomurai (MUSM 3888) comes from uppermost Miocene (i.e. upper Messinian) deposits of the Pisco Formation exposed at the Sacaco locality $\left(15.5426^{\circ} \mathrm{S}, 74.7336^{\circ} \mathrm{W}\right)$; these deposits have recently been dated at c. 5.8-5.7 Ma based on strontium isotope stratigraphy and radiometric dates provided by Ehret et al. (2012) and DO (unpub. data) (see Geological Setting, above, for more details).

\section{Description}

General features of the cranium. The holotype cranium of K. danomurai (Table 1) has a preserved length of $25.9 \mathrm{~cm}$ (measured from the anteriormost preserved point of the premaxilla to the posterior end of the nuchal crest) and a greatest supraorbital width of $24.1 \mathrm{~cm}$. The preserved skull region indicates that the original cranium was larger than those of Koristocetus and S. totajpe, which are known from geologically older layers of the Pisco Formation (Collareta et al. 2017; Benites-Palomino et al. $2020 a$ ), and similar in size to that of modern Kogia spp. Most of the cranial sutures are fully closed, indicating that the animal was a full-grown adult (Chen et al. 2011). Only a small portion of the rostrum base is preserved. However, it indicates that the rostrum was dorsoventrally flattened, similar to other Kogiinae, and its dorsal region was concave, serving as the base for the facial organs. The external bony nares are located slightly posterior to the antorbital processes, as observed in Koristocetus, Pliokogia and Nanokogia, whereas the external bony nares in modern Kogia are much more posteriorly displaced. The supracranial basin resembles that of Pliokogia appeninica (Collareta et al. 2019) and extant Kogia spp. in being divided into three main cavities (i.e. the premaxillary fossa and the left and right maxillary fossae) due to the presence of a more or less longitudinally elongated sagittal facial crest. However, it differs from the condition observed in Pliokogia (Collareta et al. 2019) and extant Kogia spp. by not possessing a complete right wall of the 


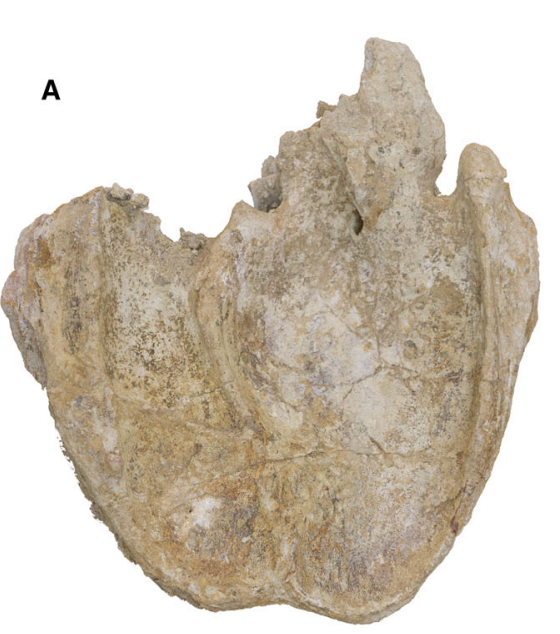

C

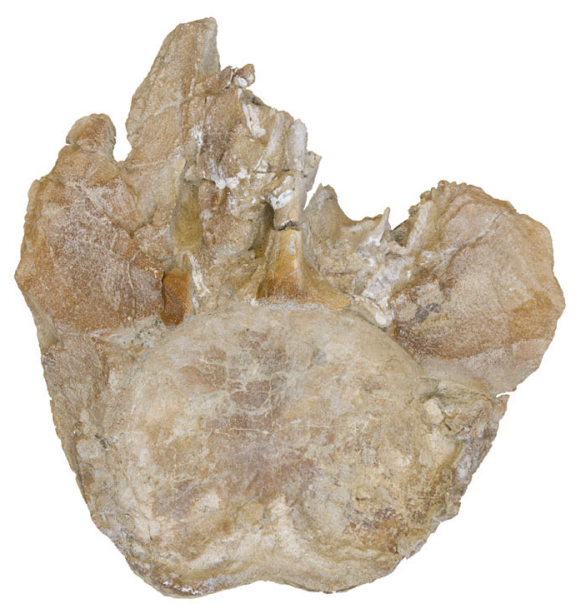

E

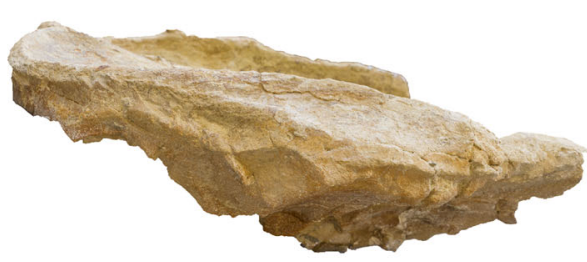

G

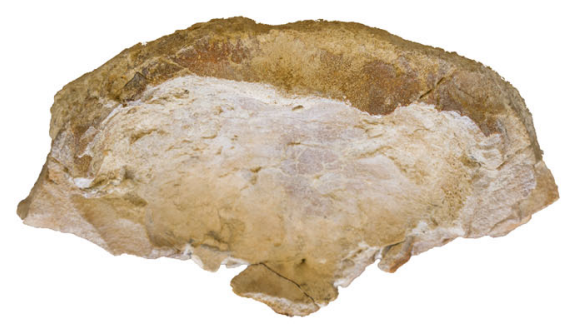

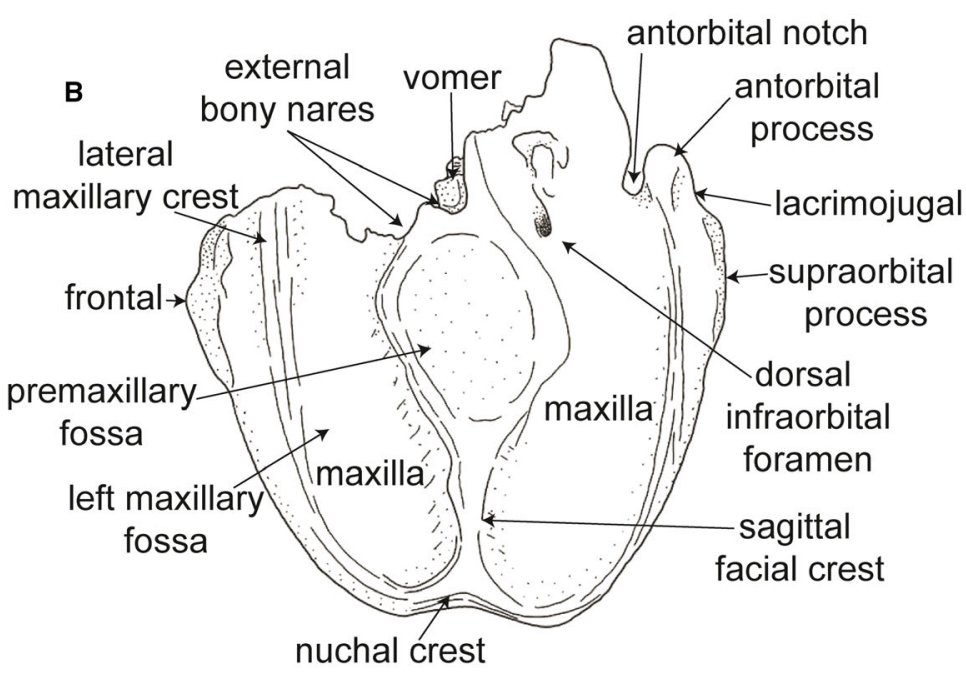

D

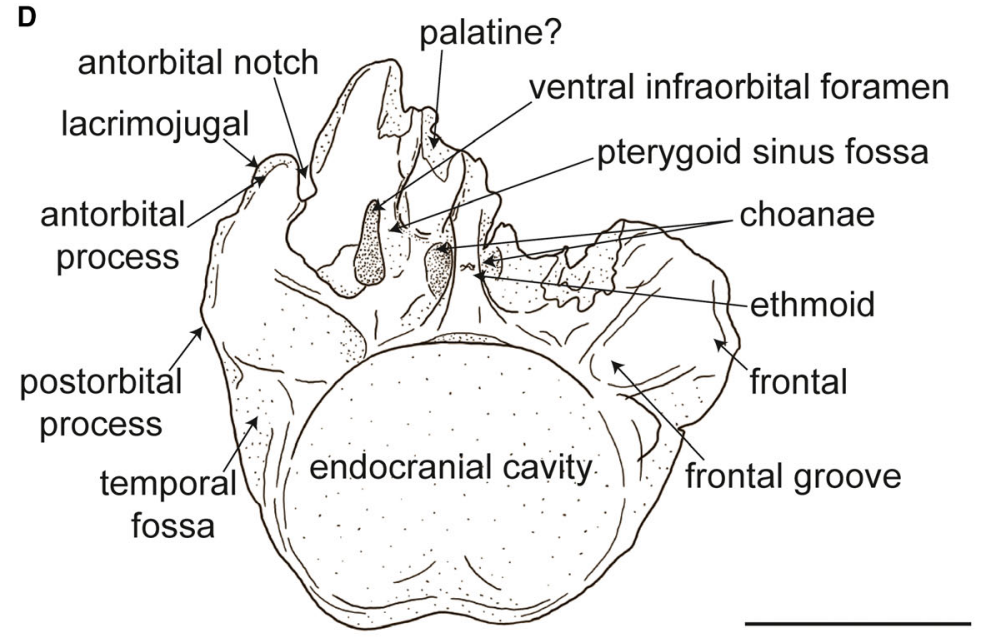

F

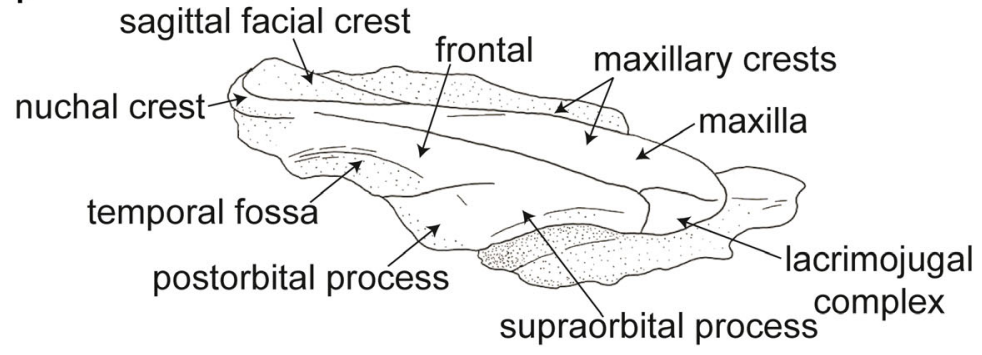

H

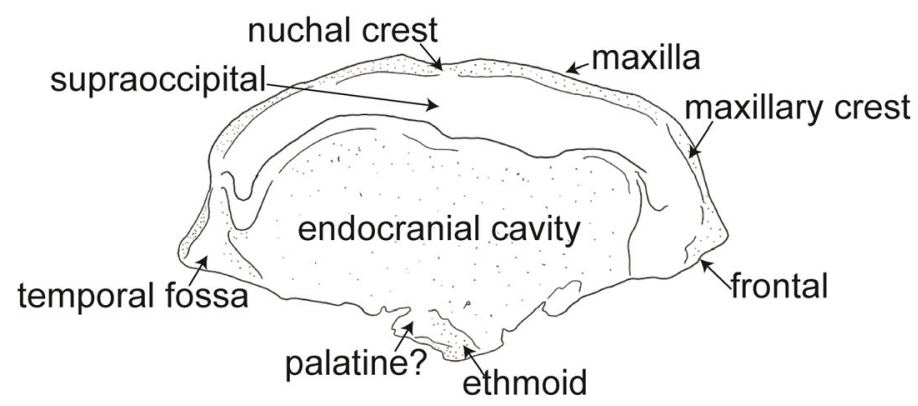

FIG. 3. MUSM 3888, holotype and only known specimen of Kogia danomurai sp. nov., photographs and schematic drawings of the holotype skull in: A-B, dorsal; C-D, ventral; E-F, right lateral; G-H, posterior view. Scale bar represents $10 \mathrm{~cm}$. 
TABLE 1. Measurements (in $\mathrm{mm}$ ) of the skull of Kogia danomurai sp. nov. (MUSM 3888).

Preserved condylobasal length

Length of the preserved portion of the rostrum

Width of rostrum at base

Maximum width of the external right bony naris

Maximum width of the external left bony naris

Greatest preorbital width (width across preorbital processes)

Greatest postorbital width (width across postorbital

processes)

Least supraorbital width

Maximum width of external nares

Greatest parietal width, within post-temporal fossae

Greatest length of temporal fossa

Length of right orbit from apex of preorbital process of

frontal to apex of postorbital process

Length of antorbital process of left lacrimal taken horizontally

Modified from Benites-Palomino et al. (2020a, table 1). e, estimated value; $\dagger$, measurement taken on incomplete element.

premaxillary fossa of the sagittal facial crest, a condition that is somewhat reminiscent of Praekogia (Barnes 1973).

Premaxilla. Only a small portion of the right premaxilla is preserved at the rostrum base, suggesting that the dorsal surface of the premaxillae was shallowly concave upwards. In the neurocranial region, only the right premaxilla is preserved, lateral and posterior to the external bony nares. Anteriorly, the right premaxilla forms the walls of the right bony naris, along with the vomer and the presphenoid. The right bony naris has an approximate anteroposterior length of $2.5 \mathrm{~cm}$ and a transverse width of $2.1 \mathrm{~cm}$. Both nasal bones are lacking, as observed in all kogiids for which this region is known. The left naris is preserved only along its posterior edge; however, as in all physeteroids, it is clearly larger than the right one. Posterior to the right bony naris, the dorsal surface of the premaxilla forms a step, which is more prominent on the left side. The sagittal facial crest is moderately displaced towards the left side of the skull, being weakly bent leftwards from the level of the antorbital notch to the level of the anterior limit of the temporal fossa, thus slightly overhanging the left maxillary fossa. The posterior portion of the crest runs along the sagittal plane of the skull, joining the nuchal crest posteriorly. Posteromedial to the nares the sagittal facial crest expands transversely to form a large depression that extends onto the right maxilla. Posterior to this depression, the sagittal facial crest tapers transversely, reacquiring a median position. In this region, the depression that is found on the premaxilla is laterally delimited by a keeled prominence that faces the right side of the skull. Considering also that it is significantly deeper than the rest of the supracranial basin (see description of the maxilla below), it is here interpreted as the premaxillary fossa (Barnes 1973). In both the living species $K$ sima and $K$. breviceps the premaxillary fossa is well-defined and excavated upon a dorsal promontory of the sagittal facial crest. The premaxillary fossa is laterally delimited by the right premaxillary and medial crests (sensu Thornton et al. 2015; Fig. 3). Ventrolaterally, these crests serve as the attachment sites for the facial muscles on the left side and for the case on the right (Thornton et al. 2015). K. danomurai displays an incipient, early-stage development of these characteristics, given that the premaxillary fossa is not completely separated from the right maxilla, being anteriorly delimited by a bulging margin of the postnarial eminence at the level of the right posterior dorsal infraorbital foramen.

Maxilla. As for the premaxillae, only a small portion of the right maxilla is preserved on the rostrum. The preserved rostral portion of the maxilla indicates that its dorsal surface was flat to slightly convex. The rostrum is dorsoventrally flattened, and, in anterior view, it presents a slightly V-shaped transverse section, implying that the supracranial basin extended onto the rostrum as observed in Kogia breviceps, K. sima and K. pusilla. On the right maxilla, a single dorsal infraorbital foramen is preserved; it is medially located near the suture with the right premaxilla and at a level posterior to the corresponding antorbital notch, reaching an anteroposterior length of $1.3 \mathrm{~cm}$ and a transverse width of $0.8 \mathrm{~cm}$. Due to the loss of more rostral portions of the maxilla, it is not possible to ascertain whether one or more anterior dorsal infraorbital foramina were present in K. danomurai. Unlike other kogiids such as Nanokogia, Praekogia, Koristocetus or Pliokogia, no posterior dorsal infraorbital foramina are present in the area of the right maxillary fossa. The supracranial basin has an ovoid outline, being longer than wide, but not as deep as in extant Kogia. The supracranial basin is anteromedially deeper, being shallower and slightly convex transversely in its posterior portion. Posteriorly, the maxillary fossae are separated from each other by the ridge-like posterior projection of the sagittal facial crest; this condition is somewhat reminiscent of that observed in Pliokogia and in modern Kogia. The right maxillary fossa is reniform and transversely compressed, only moderately widening posteriorly. The well-preserved right antorbital process is transversely thickened, thus differing from most fossil kogiids that display a transversely compressed antorbital process (e.g. Aprixokogia). This condition is even more developed in $K$. sima and K. breviceps, where the antorbital process is greatly inflated (i.e. hyperostotic) and displays an overall bulbous aspect. The maxillary crests are transversely narrow and moderately high over the dorsal level of the supracranial basin, as observed in Nanokogia and Koristocetus. The lateral maxillary crests run roughly parallel to each other along the dorsal surface of the cranium, bending medially on the posterior third of the cranium to form the nuchal crest by coalescence. Posteriorly, the nuchal crest is joined medially by the sagittal facial crest, thus forming a W shape, being slightly asymmetric due to weakly posterior enlargement of the right maxillary fossa. The $\mathrm{W}$ shaped outline of the nuchal crest is found only in taxa in which the sagittal facial crest reaches the nuchal crest, including the extant Kogia spp., Praekogia and, to a lesser extent, in Nanokogia. This condition might have also been present in Koristocetus, as suggested by the position of the sagittal facial crest; however, the holotype skull is missing most of the nuchal crest. In ventral 
view, the preserved portion of the palatal surface of the maxilla is flat. The preserved ventral portion of the rostrum on the right side of the skull indicates that $K$. danomurai did not present functional posterior alveoli, thus resembling other coeval Kogiinae in which reduced maxillary alveoli (or even a narrow alveolar groove) are retained. Preserved only on the right side of the skull, the ventral infraorbital foramen is anteroposteriorly oriented and opens at a level slightly posterior to that of the corresponding antorbital notch, being shaped as a large furrow that reaches $3.5 \mathrm{~cm}$ in anteroposterior length and $1.1 \mathrm{~cm}$ in transverse width. The endocranial cavity has a cordiform outline in ventral view. It narrows anteriorly and exhibits a medial notch posteriorly.

Vomer. Only the posteriormost region of the vomer is preserved. Posteriorly, along with the ethmoid, the vomer creates a wall that separates both the left and right internal choanae from each other. The vomer runs anteriorly along with the ethmoid. The posteriormost preserved portion of the vomer flares dorsolaterally, and, as such, it exhibits a triangular outline in transverse section.

Ethmoid. The ethmoid is anteriorly broken, along with the rest of the rostrum. In anterior view, the transversely broken surface of the ethmoid displays an elliptical, mediolaterally elongated outline. The preserved region of the ethmoid has a length of $8.1 \mathrm{~cm}$ and narrows medially, thus creating a waist-like compression at mid-length that forms most of the nasal septum. The ethmoid broadens posteriorly, being broken at the level of the cribriform plate. The ethmoid mostly consists of spongy bone and exhibits a thicker periosteum compared with the adjacent bones.

Lacrimojugal complex. The lacrimojugal complex is preserved only on the right side of the skull, lacking the ventral portion of the preorbital process. As in Scaphokogia totajpe and Nanokogia isthmia, the lacrimojugal complex sends a small, distally tapering projection that wedges between the maxilla and the frontal. Ventrally, the attachment site of the m. masseter is more developed than in Koristocetus and Nanokogia, but not as transversely widened as in K. breviceps and K. sima.

Frontal. The frontal is dorsoventrally compressed and appressed to the overlying maxilla. In lateral view, the suture between the maxilla and the frontal is straight and forms a $25^{\circ}$ angle relative to the horizontal plane. In dorsal view, the supraorbital processes protrude laterally beyond the level of the maxillary crests, thus exposing a small strip of each frontal, as in other kogiids. Ventrally, the frontal grooves are excavated and progressively bend laterally, thus approaching the condition observed in extant Kogia, whereas other members of Kogiinae such as Koristocetus display more anteriorly oriented frontal grooves.

\section{PHYLOGENETIC ANALYSIS}

The anatomical characters of $K$. danomurai were coded into the matrix of Benites-Palomino et al. (2020a).
Subsequent amendments on Kogia pusilla were based on direct observations of the holotype cranium. The final matrix includes 34 taxa and 57 characters and was edited using Mesquite 2.75 (Maddison \& Maddison 2011; Benites-Palomino et al. 2020b). A preliminary heuristic search was performed using PAUP (version 4.0a [build 167]) (Swofford 2002), using the tree bisection and reconnection (TBR) algorithm, with equal weights for all characters. Because of the poor resolution of this analysis (Fig. 4A), and in order to further evaluate the matrix consistency and the character performance, a series of subsequent parsimony analyses was performed. With the aim of focussing only on the relationships among extant and fossil pygmy sperm whales, the ingroup was restricted to Kogiidae on the following analyses, leaving the outgroup composed of non-kogiid sperm whales, stem odontocetes, and archaeocetes. For our second analysis, all characters were also treated as unordered, but we downweighted homoplasic characters by using the implied weighting method (Fig. 4B), with the default value of 2 for the constant $k$ (Goloboff 1993). Two additional analyses were performed using the same methodology as the previous analyses (Fig. $4 \mathrm{C}, \mathrm{D}$ ), but considering the characters $1,3,4,10,12,18,22,25,26,30,32,34$, and 38 as ordered, in agreement with the approach that has recently been proposed by Paolucci et al. (2020). Following previous works (Lambert et al. 2010; Paolucci et al. 2020) that combined implied weighting with the use of ordered characters, we prefer the fourth analysis (Fig. 4D) by virtue of its overall better node resolution. The fourth analysis strongly supports the monophyly of Kogiidae on the basis of 13 synapomorphies, namely: maxillae, premaxillae, and vomer reaching the tip of the rostrum (char. 2 [1]); maximum width of the skull, bizygomatic or postorbital width, less than $40 \mathrm{~cm}$ (char. $8[0]$ ); three to four dorsal infraorbital foramina in the area of the right antorbital notch or posterior to it (char. 11[0]); right premaxilla not widened posteriorly (char. 13[0]); sagittal crest present and shaped as a shelf covered by the pointed right premaxilla (char. 14[1]); both nasals absent (char. 19[2]); right maxilla reaching the sagittal plane of the skull on the posterior wall of the supracranial basin (char. 21[1]); long projection of the lacrimojugal complex between the frontal and the maxilla (char. 23[1]); temporal fossa anteroposteriorly longer than the distance between the preorbital process of the maxilla and the anterior wall of the temporal fossa (char. 26[0]); posterior extension of the periotic parallel to the general plane of the bone, and not ventrally oriented (char. 33[1]); lack of contact between the jugal and the zygomatic process of the corresponding squamosal (char. 45[2]); short dorsal process of the periotic (char. 48[2]); and symphyseal angle on the mandibles greater than $55^{\circ}$ (char. 51[2]). Previous work (Benites-Palomino et al. 2020a; Collareta et al. 2020) 

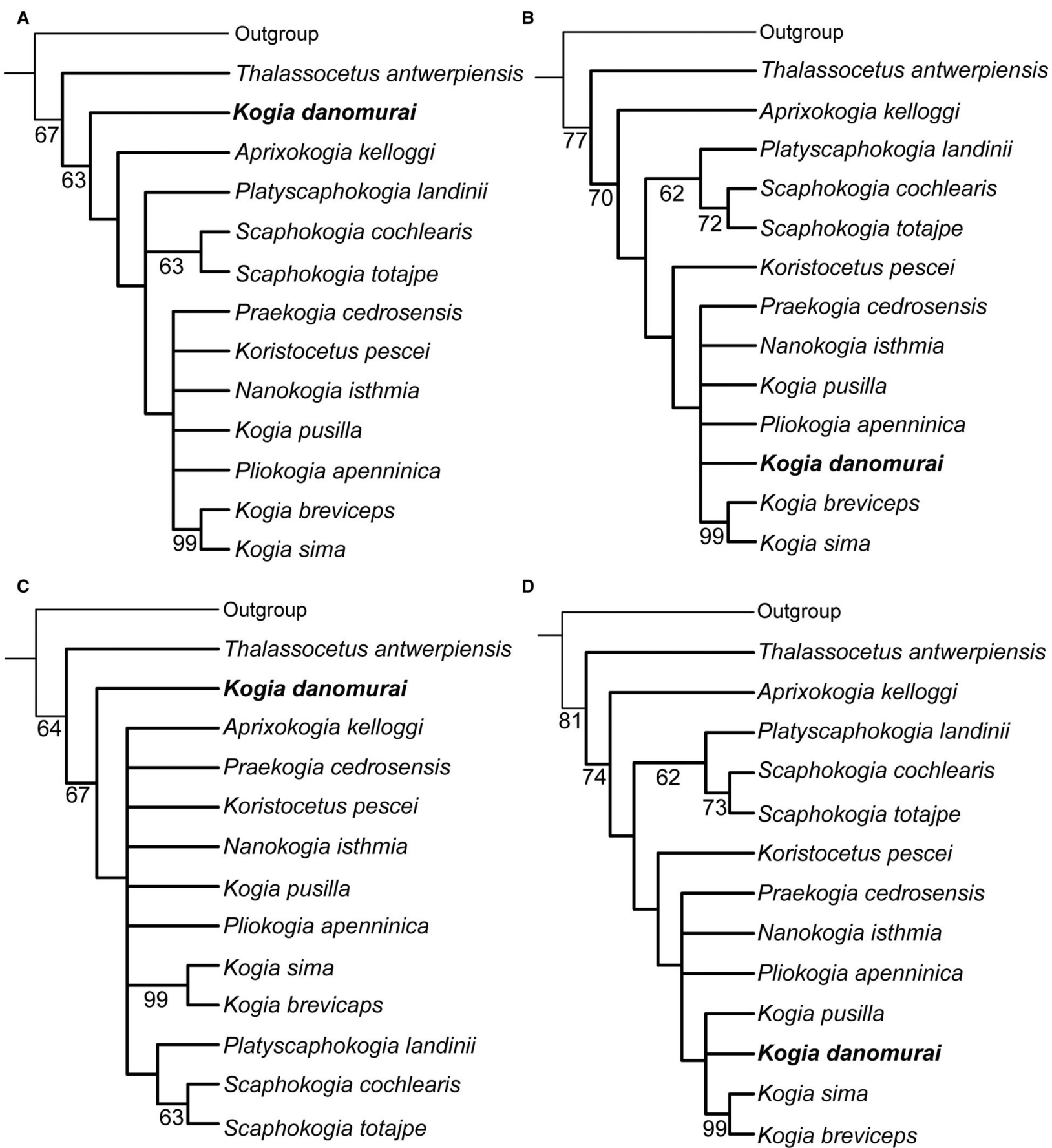

D

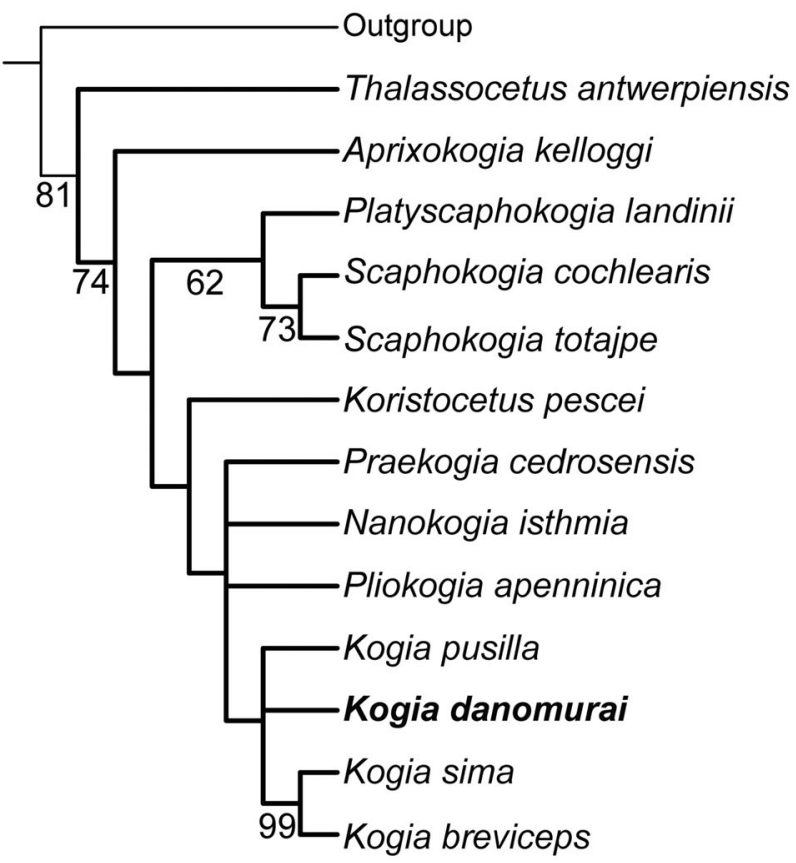

FIG. 4. Phylogenetic relationships of Kogia danomurai sp. nov. with other kogiids. A, strict-consensus tree of the full heuristic search resulting from 576 trees, each 178 steps long, with retention index $(\mathrm{RI})=0.743$ and consistency index $(\mathrm{CI})=0.494$. B, strict-consensus tree of the implied weights $(\mathrm{k}=2)$ search resulting from 90 trees, each 182 steps long, with $\mathrm{RI}=0.731$ and $\mathrm{CI}=0.484$. C, strict-consensus tree of the heuristic search with ordered characters weighting resulting from 17784 trees, each 206 steps long, with RI $=0.753$ and $\mathrm{CI}=0.539$. D, strict-consensus tree of the implied weights analysis with ordered characters resulting from 135 trees, each 211 steps long, with $\mathrm{RI}=0.740$ and $\mathrm{CI}=0.526$.

supported the presence of two conspicuous clades among Kogiidae, namely, Scaphokogiinae and Kogiinae. The former are recovered on the basis of the following characters: suture between the premaxilla and maxilla distinctly anterolaterally directed anterior to the antorbital notches (char. 5[1]); right premaxillary foramen posterior 


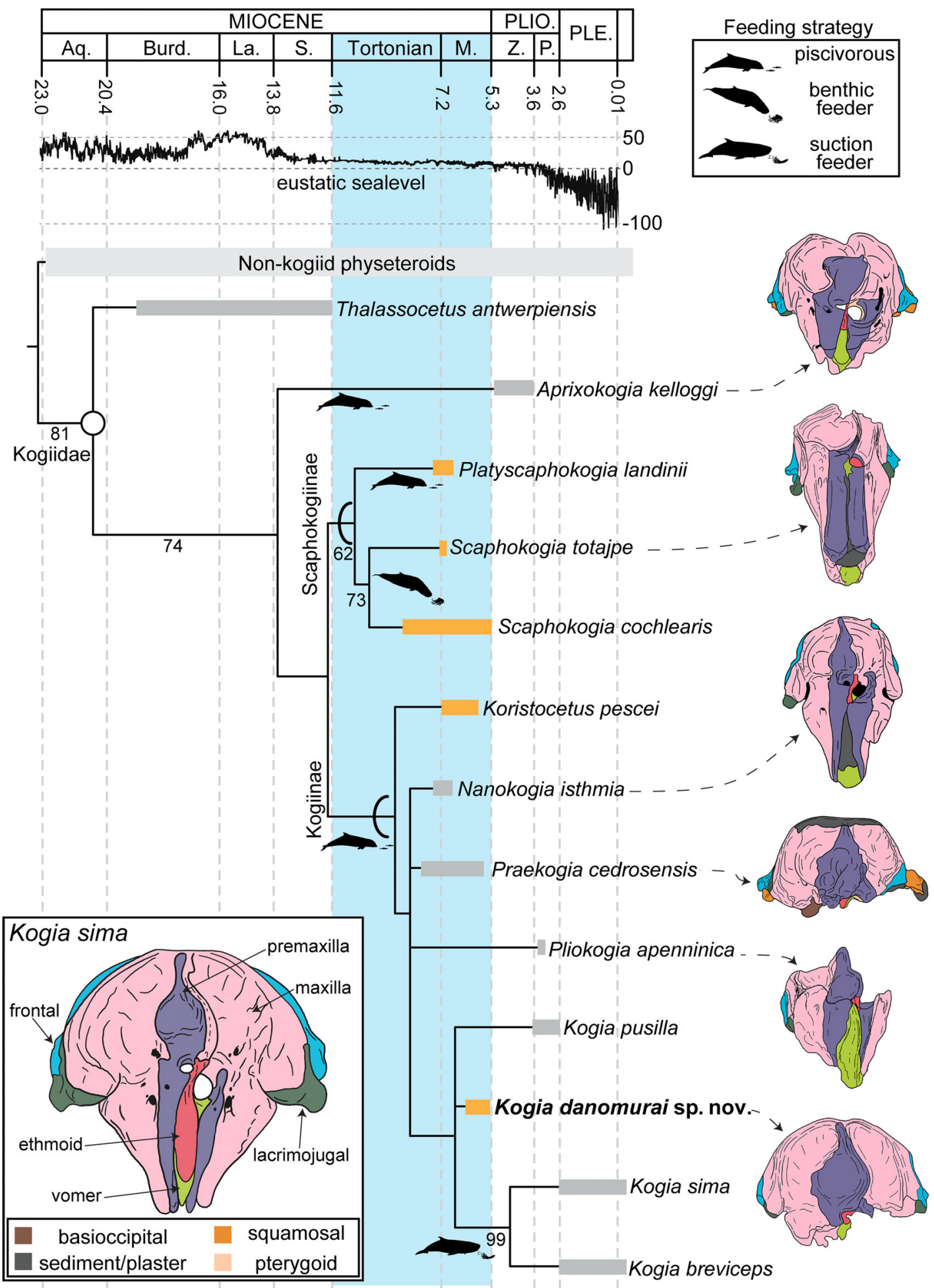

FIG. 5. Time-calibrated phylogenetic relationships of Kogiidae and cranial variations among different genera. Strict-consensus tree of Kogiidae based on 135 most parsimonious trees, each 211 steps long, with retention index (RI) $=0.740$ and consistency index $(\mathrm{CI})=0.526$ (see Fig. 3D). Arcs denote branch-based clades, circle denotes node-based clade, numbers at nodes indicate bootstrap values. The time scale is based on Cohen et al. (2020), eustatic sealevels are after de Boer et al. (2010). Abbreviations: Aq., Aquitanian; Burd., Burdigalian; La., Langhian; M., Messinian; P., Piacenzian; Ple., Pleistocene; Plio., Pliocene; S., Serravallian; Z., Zanclean. 
to the corresponding antorbital notch (char. 17[1]); occipital shield flat or concave, forming an angle greater than $90^{\circ}$ with the horizontal (char. 30[3]); hypertrophy of the mesorostral canal, in which the canal occupies more than $50 \%$ of the rostrum diameter (char. 57[1]). The members of the second clade, Kogiinae, are recognized by the following synapomorphies: short rostrum, ratio of the rostrum length to skull width $<0.95$ (char. 1 [2]); dorsal exposure of the maxilla on the rostrum wider than the premaxilla all along (char. 4[2]); right antorbital notch entering the supracranial basin (char. 10[1]); in lateral view, presence of a well-developed, wide notch posterior to the postglenoid process of the squamosal for the enlarged posterior process of the tympanic (char. 29[2]); occipital shield convex and forming an angle of $c .60^{\circ}$ with the long axis of the rostrum (char. 30[1]).

The clade including the four species of Kogia is supported by the following synapomorphies: supracranial basin extended onto the whole surface of the rostrum (char.3[2]); occipital shield flat or slightly concave, forming an angle of $c .90^{\circ}$ (char. 30[2]); and mandible curved in lateral view, with its ventral margin concave (char. 50 [2]; known only in extant taxa). Kogia pusilla is diagnosed by two derived characters: anteroposterior level of the last upper alveoli or posterior vestigial alveolar groove placed at the level of the antorbital notch or slightly anterior (char. 41[1]); and postorbital process of the frontal moderately extended posteroventrally (char. 43[0]). Kogia danomurai differs from other species of Kogia by these four characters: antorbital notch not transformed into a narrow slit (char. 9[1]); one large dorsal infraorbital foramen present in the area of the right antorbital notch (char. 11[3], shared with Koristocetus); short projection of the lacrimojugal between the frontal and the maxilla (char. 23[0], shared with Nanokogia); and dorsal margin of the temporal fossa at the top of skull or somewhat lower (char. 44[0]). The monophyly of the clade formed by Kogia breviceps and Kogia sima is supported by two characters: frontal-maxilla suture forming an angle greater than $35^{\circ}$ with the skull in lateral view (char. 25 [2]); and temporal fossa distinctly shorter than the distance between the preorbital process of the maxilla and the anterior wall of the temporal fossa (char. 26[2]).

\section{DISCUSSION}

Phylogenetic relationships of $\mathrm{K}$. danomurai within Kogiidae

Kogia danomurai is geologically the oldest species of the genus Kogia known so far. As such, it significantly extends the chronostratigraphic range of Kogia into the upper Miocene while further enriching the taxonomically diverse physeteroidea assemblage of the Pisco Formation.
Previous work has already stressed the presence of several species of physeteroids, including macroraptorial taxa (Lambert et al. 2008, 2016), large suction feeders (Muizon 1988; Benites-Palomino \& Urbina 2020), small piscivorous animals and benthic feeders in the Pisco strata (Benites-Palomino et al. 2020a; Collareta et al. 2020). So far, seven physeteroid species have been described from the Pisco Formation, but the relationships among specieslevel sperm whale taxa as well as those between the major physeteroid clades are constantly changing as new fossils allow for testing of new phylogenetic hypotheses. The only well-supported clade in most recent phylogenetic reconstructions is Kogiidae.

The monophyly of Kogiidae has indeed been widely supported by both molecular (McGowen et al. 2009, 2019; Geisler et al. 2011) and morphological analyses (Velez-Juarbe et al. 2015; Collareta et al. 2017, 2019, 2020; Benites-Palomino et al. 2020a; Lambert et al. 2020). According to the morphological assessments proposed in the present study (Fig. 5), one of the earliest branching kogiids was the early Pliocene Aprixokogia kelloggi from North Carolina, south-eastern USA (Whitmore \& Kaltenbach 2008), known from a skull that retains several primitive physeteroid characteristics. This indicates that stem kogiids retaining plesiomorphic characters were able to survive until fairly recent times, with their chronostratigraphic ranges overlapping those of derived forms such as Kogia (Vélez-Juarbe et al. 2016). Two conspicuous clades of morphologically derived kogiids, Scaphokogiinae and Kogiinae, have been recovered by recent phylogenetic analyses, highlighting the role of the Pisco Formation as a hotspot for kogiid diversification during the late Miocene (Benites-Palomino et al. 2020a; Collareta et al. 2020). Scaphokogiinae are, so far, restricted to the Pisco Formation of southern Peru $\left(12^{\circ}-\right.$ $\left.16^{\circ} \mathrm{S}\right)$. The skeletal morphology of the rostrum of these animals greatly contrasts with that of other kogiids due to the hypertrophied mesorostral canal that occupies more than half of the inner region of the rostrum. Additionally, the facial region of the skull is mostly occupied by the large, deeply excavated supracranial basin, which displaces the sagittal facial crest laterally; this supracranial basin is nonetheless not extended onto the rostrum as in other kogiids (Muizon 1988; Benites-Palomino et al. 2020a). Three species, clustered in two genera, are recognized in this clade: Platyscaphokogia landinii, characterized by its relatively narrow and transversely compressed rostrum; and Scaphokogia, which includes the sister taxa Scaphokogia cochelaris and Scaphokogia totajpe, diagnosed by a tube-like rostrum. Scaphokogiines have been interpreted as benthic feeders because of their anteroventrally deviated rostrum and the pachyostotic growth of the cranial bones on the rostrum (Benites-Palomino et al. 2020a; Collareta et al. 2020). 
The second clade, Kogiinae, includes an array of several taxa that display different evolutionary stages of their suction-feeding capabilities. Ranging from taxa that either retained functional upper teeth, such as Koristocetus, or lack an upper dentition, such as extant Kogia spp. Furthermore, these species display a great variability in terms of the arrangement of the nasal organs placed over their foreheads, as revealed by the dorsal aspect of their skulls (see below). Nevertheless, the general aspect of the skull in kogiines, and in scaphokogiines, can be distinguished by the overall triangular outline of the skull, proportional reduction in size of the temporal fossa, the lack of a deep spoon-shaped supracranial basin and the presence of three cavities in the supracranial basin (left and right maxillary fossae and a medially located premaxillary fossa). Within Kogiinae, relationships between taxa have been mostly consistent in recent analyses (Collareta et al. 2017, 2019: Benites-Palomino et al. 2020a). The earliest branching Kogiinae is Koristocetus, a taxon that displays several plesiomorphic characteristic such as the retention of a proportionally larger temporal fossa and the presence of functional upper dentition. The external bony nares of Koristocetus are also found in the anteriormost position among the clade. The next node includes Pliokogia and Nanokogia, characterized by the reduction in size of the temporal fossa and the lack of a supracranial basin extended into the rostrum (Collareta et al. 2019). In the case of Praekogia, because the rostrum and the anteriormost left facial region are missing, it is not possible to assess whether the supracranial basin extended into the rostrum or not. However, the overall shape of the basin and its extension indicates that it was smaller than in Kogia. This condition is more evident in dorsal view, because both the postorbital region of the frontal and the zygomatic process are well-laterally projected.

Differing from the rest of Kogiinae, Kogia are characterized by an evident extension of the supracranial basin into the rostrum. This condition is partly developed on the rostrum of $K$. pusilla, due to its narrower profile anteriorly. In $K$. danomurai it is not possible to assess if this was as well-developed as in extant Kogia or partly developed as in K. pusilla. However, based on the concave surface of the preserved portion of the rostrum, the supracranial basin should have been well-extended into the rostrum. Furthermore, in both K. pusilla and $K$. danomurai the orbital region is not as laterally projected as in Praekogia, indicating that the supracranial basin occupied most of the dorsal region of the skull as in extant Kogia spp. Additionally, extant Kogia spp. displays the most derived suction-feeding skull morphology of extant odontocetes (Werth 2006), characterized by a short triangular rostrum (i.e. amblygnathy). Specific development of the masticatory muscles also provides evidence for this: in Kogia, the m. masseter is the main mandibular adductor (Schulte \& Forest Smith 1918; Benites-Palomino et al. 2020a), contrasting with raptorial taxa such as Acrophyseter, in which mandible adduction is done by the m. temporalis (Lambert et al. 2014, 2016). Because of its longer rostrum and the size reduction of the $\mathrm{m}$. masseter attachment site, in K. pusilla these suction-feeding capabilities were not as developed as in extant Kogia spp., and therefore K. pusilla should have retained some raptorial feeding capabilities, such as those of Nanokogia or Pliokogia for ram prey capture (Hocking et al. 2017; Fig. 2D). In K. danomurai most of the rostrum is not preserved, thus making it impossible to reconstruct its overall shape. However, the ventral area of the lacrimojugal of $K$. danomurai is proportionally the largest among fossil kogiids, thus indicating that the $\mathrm{m}$. masseter was already playing an important role in the mandibular adduction for suction feeding, as in extant Kogia spp.

\section{Patterns of compartmentalization of the facial region of the} skull

Unlike Physeter, which exhibits greatly hypertrophied spermaceti and melon organs (Clarke 1970), the living species of Kogia bear additional soft structures, the roles of which are still not fully understood. Because of their greatly developed facial asymmetry (highlighted also by the sound production pathways of the forehead; Goold \& Clarke 2000) and proportionally smaller size, the function of the soft-tissue structures in Kogia might have undergone a secondary adaptation or compartmentalization, in which functions were split into specific structures. Such a differentiation in the role of certain regions of the forehead has been suggested in early works based on myology and cranial anatomy (Schulte 1917; Schulte \& Forest Smith 1918). Modern descriptions of the organs and other soft-tissue structures indicate that there are four main anatomical structures that form the nasal complex of extant Kogia (Thornton et al. 2015): (1) the phonic lips, which produce the sound via phonation when the air from the right nasal passage passes through; (2) the spermaceti organ, which is restricted to the facial region of the skull, highly influenced by the skeletal muscles in the region of the premaxillary fossa (Schulte \& Forest Smith 1918), and believed to take an active part in sound propagation and transmission; (3) the 'vocal' cap, or 'cushion' (Clarke 2003), which lies on the right maxillary fossa and has been suggested to modulate the sound via muscular control; and (4) the melon, which extends dorsally onto the rostrum and, as in other toothed cetaceans, is responsible for focusing and emitting the sound waves that are involved in echolocation (Cozzi et al. 2016). Furthermore, several air sacs and muscles are attached to the 
nasal complex, which rests in the left maxillary fossa, and within the anterodorsal region of the inflated lateral maxillary crests (Clarke 2003; Thornton et al. 2015). As in Physeter, these complex structures are modulated by highly vascularized surrounding muscles that act as a pneumatic sound generator (Norris \& Harvey 1972). This is evidenced by the homologous attachment regions for the facial muscles found in the forehead of Kogia (Schulte \& Forest Smith 1918). All of the non-muscular structures have different densities, acoustic impedances and sound velocity responses, thus evoking specific roles in the sound production system of kogiids. Computed tomography has confirmed the presence of a fifth structure, the theca (sensu Song et al. 2015), which covers the entire nasal complex of modern Kogia, being mostly constituted by dense connective tissue. Based on this characterization, this structure might be homologous to the 'case' described by Clarke (1978) for Physeter macrocephalus.

Fossil Kogiidae display several evolutionary stages of these structures, along with different feeding strategies, as suggested by their cranial anatomy. In Aprixokogia kelloggi, one of the earliest diverging kogiids (Fig. 5), the supracranial basin is partially divided by a robust, transversely broad, sagittal facial crest, which ends some $5 \mathrm{~cm}$ anterior to the nuchal crest. The reduced sagittal facial crest is also found in Scaphokogiinae, in which it is also displaced leftwards. The dorsal surface of the sagittal facial crest is shallowly concave, probably indicating the position of the base of the spermaceti organ. Furthermore, the sagittal facial crest exhibits a slightly developed lateral right premaxillary crest and a medial crest; in modern Kogia, these structures delimit the receptacle-like premaxillary fossa (sensu Thornton et al. 2015, fig. 4). Because of the poor development of the lateral walls of the premaxillary fossa and shallowness of the latter, the spermaceti organ of Aprixokogia could have been proportionally smaller than in other kogiids. A small spermaceti organ would have limited the high-frequency sound production capabilities of this extinct species, thus implying that its preying strategies greatly differed from its extant relatives. This is also highlighted by the retention of welldeveloped functional upper teeth, which suggest a raptorial ecology, rather than the less active suction feeding, for Aprixokogia. Further insights into the paleoecology of Aprixokogia could derive from the study of periotics referable to this taxon. A periotic (LACM 37258) from the Yorktown Formation that is likely to represent A. kelloggi (Vélez-Juarbe et al. 2016), has a cochlear morphology that resembles that of macroraptorial odontocetes (e.g. Acrophyseter) and lacks the specializations observed in extant Kogia (Galatius et al. 2019).

In Scaphokogiinae, the facial bone patterning is not as disparate as in their sister group (Kogiinae), given that scaphokogiines do not possess a true premaxillary fossa.
In turn, the enlarged right maxillary fossa (sensu BenitesPalomino et al. 2020a) is very large, deep, and occupies most of the dorsal region of the skull, thus displacing leftwards the overly reduced left maxillary fossa (Fig. 6). Because of this, it is not possible to ascertain whether the spermaceti organ or the vocal cap were largely developed on the right maxillary fossa. It seems reasonable to hypothesize that the spermaceti organ occupied most of this cavity and was dorsally covered by the vocal cap (Muizon 1988), given that most of the attachment sites of the facial muscles that modulate this organ are dorsally or anteriorly displaced (as in Scaphokogia totajpe). Despite occupying most of the facial region, the spermaceti organ of Scaphokogiinae was not hypertrophied, as in those non-kogiid physeteroids (Velez-Juarbe et al. 2015) in which it extends onto the dorsal surface of the rostrum (Lambert et al. 2016). In Scaphokogia, both the enlarged spermaceti organ and the massive tubular rostrum have been proposed to be adaptations for benthic feeding in shallow environments (Benites-Palomino et al. 2020a).

In Praekogia, Koristocetus, Kogia pusilla, Kogia danomurai, Nanokogia and Pliokogia, conspicuous differences in the skull architecture of the supracranial basin reveal a corresponding disparate organization of the soft-tissue structures. In the recently described Pliokogia apeninnica, the premaxillary fossa is located slightly posterior to the right external bony naris, and it rests well-separated from both the left and right maxillary fossae, the latter being moderately shallow and transversely compressed (Collareta et al. 2019; Fig. 6). In Kogia danomurai, the premaxillary fossa is not fully separated from the right maxillary fossa; however, posteriorly, the sagittal facial crest partially projects to the right, which partly separates these two depressions (Fig. 6). This condition is similar to the one observed in Praekogia (Barnes 1973; VelezJuarbe et al. 2015); however, the projection of the sagittal facial crest is more developed on $K$. danomurai than in the former. Furthermore, the premaxillary fossae of both K. danomurai and Praekogia extends laterally onto the right maxilla, being much rounder and robust anteriorly and expanding posteriorly over the postnarial eminence of the right premaxilla. Laterally, $K$. danomurai also displays an early stage of the transversal thickening of maxillary crests. In extant K. sima and K. breviceps (Fig. 6B), this thickening greatly enlarges the dorsal attachment sites for the muscles that modulate the nasal complex. This is evident in the anterodorsally rounder tip of the antorbital notch in $K$. danomurai. One of the main differences between Kogia spp. and the rest of the kogiids is the extension of the supracranial basin into the rostrum, an area occupied by the largest organ of the nasal complex: the melon (Fig. 6A, B). In fossil taxa such as Koristocetus or Nanokogia the rostrum is convex and narrow, indicating that the basin did not extend into the rostrum and 
A

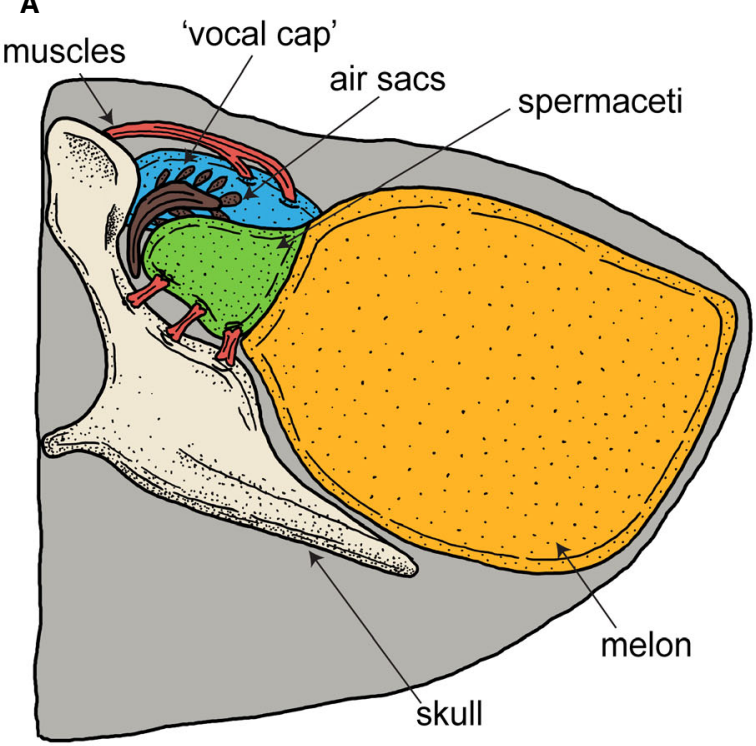

B

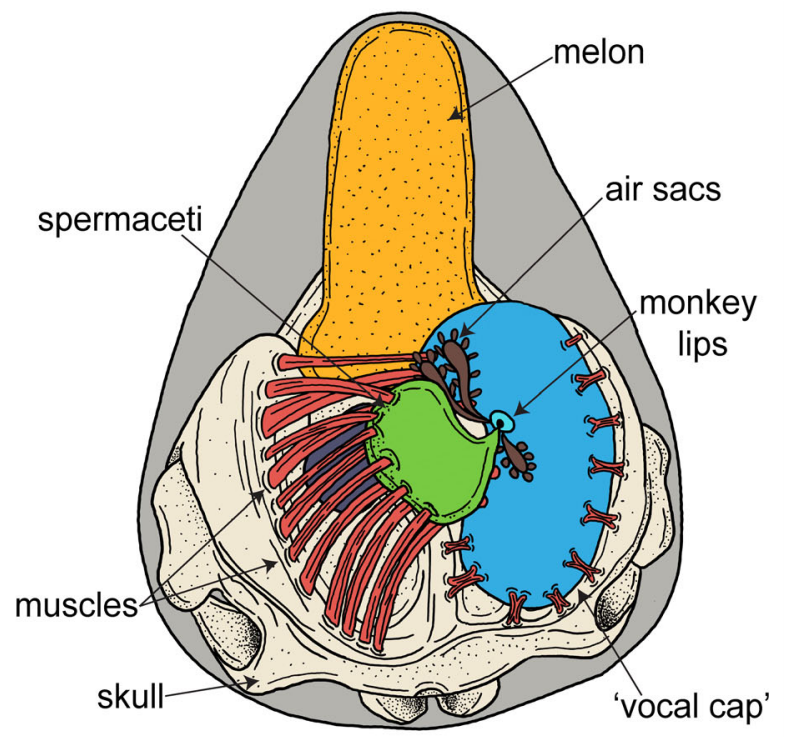

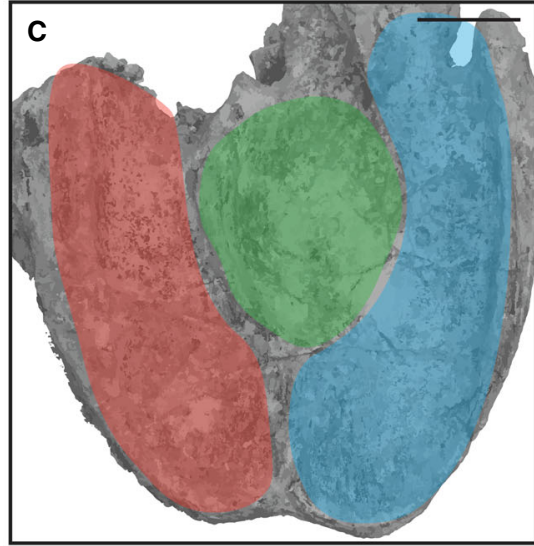

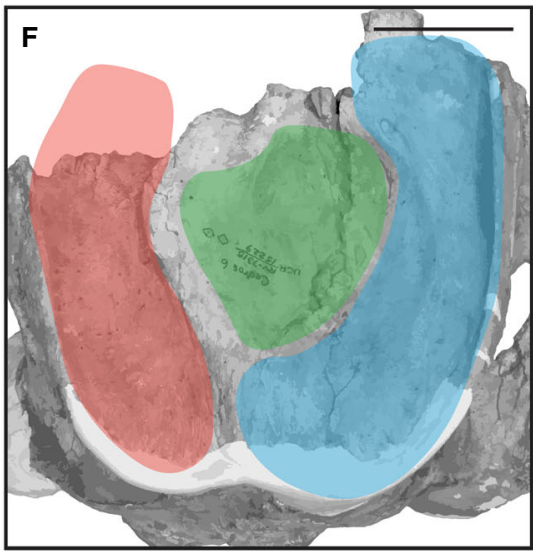

left maxillary fossa
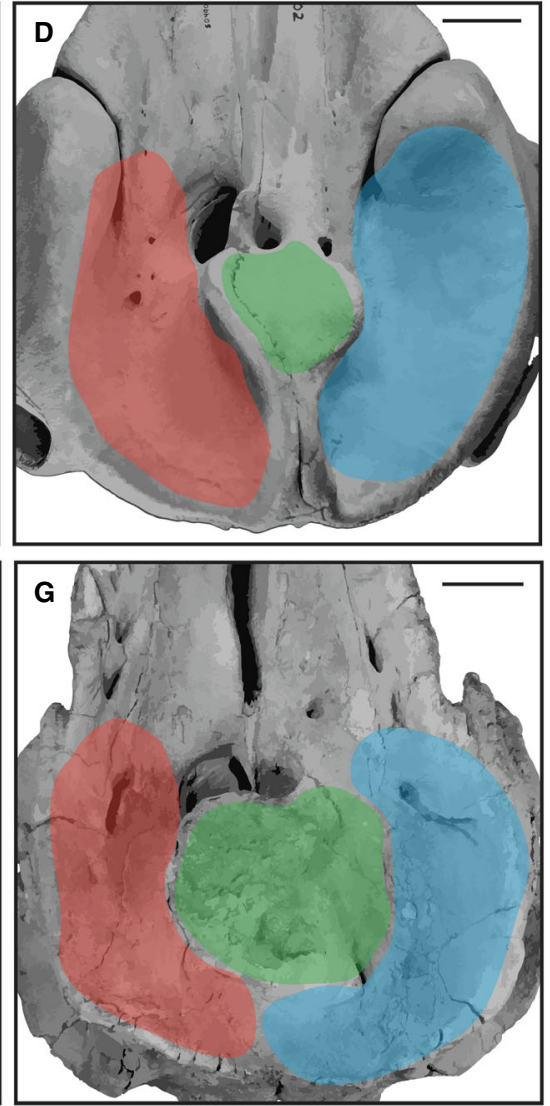

premaxillary fossa
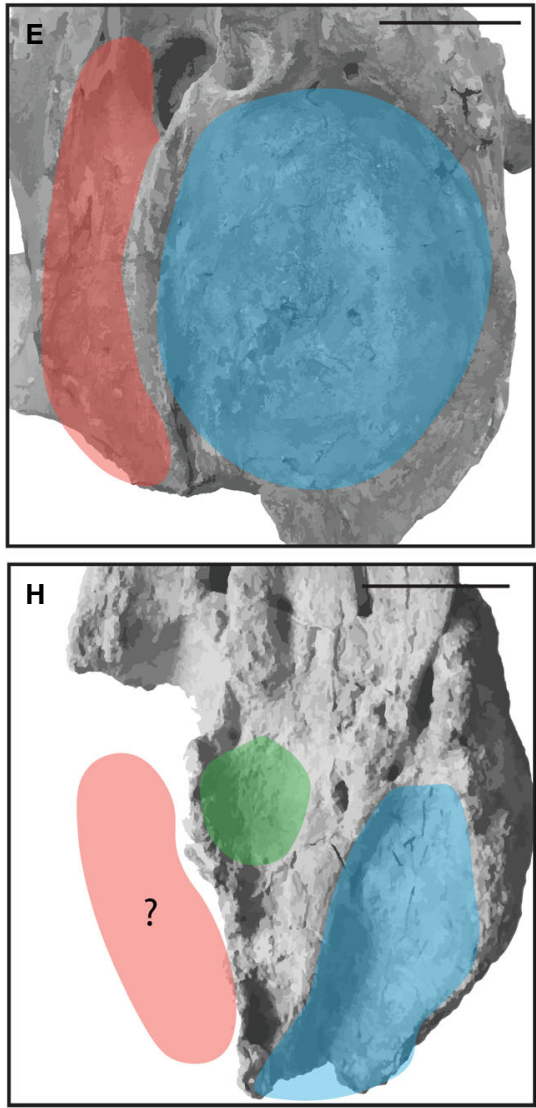

right maxillary fossa

FIG. 6. A-B, schematic representation of the soft-tissue structures present in the facial region of the head of modern Kogia breviceps, modified from Thornton et al. (2015). C-H, variation of the facial region of the skull region in several modern and fossil kogiid species: C, Kogia danomurai MUSM 3888; D, Kogia breviceps USNM 504902; E, Scaphokogia totajpe MUSM 973; F, Praekogia cedrosensis UCMP 315299; G, Aprixokogia kellogi USNM 187015; H, Pliokogia appeninica MSNUP I 17603. Scale bars represent $5 \mathrm{~cm}$. 
therefore held a smaller melon. Both K. danomurai (based on the preserved rostral fragment) and $K$. pusilla already displayed a relative extension of the basin into the rostrum, as previously discussed (see above). This larger extension of the supracranial basin and the overall development of the muscle attachment sites for modulating the nasal complex, indicate that Kogia danomurai already had a sound production system as in extant Kogia spp., but developed to a lesser extent.

\section{The hyperdiverse physeteroid community of Sacaco}

The discovery of Kogia danomurai highlights that members of the extant genus Kogia co-occurred along with other highly derived kogiids such as Scaphokogia cochlearis, the craniofacial patterning of which greatly differs from that of Kogia. Along with these, the community of physeteroids also included raptorial sperm whales as Acrophyseter deinodon, and taxa related to extant Physeter (Benites-Palomino \& Urbina 2020). Such a multi-species sperm whale community indicates the presence of a wide array of available prey items, and, as such, a niche partitioning within the physeteroid community. This hyperdiversification pattern of odontocete taxa has also been recorded in early Miocene layers, in which a large diversity of platanistoids coexisted within the Pisco basin (Bianucci et al. 2020). However, unlike other previous groups of odontocete taxa, physeteroids occupied a wide array of ecological niches ranging from raptorial to suction feeding, including several transitional forms between both mechanisms (Hocking et al. 2017).

In addition, $K$. danomurai was recovered from levels that also document the oldest records of some extant delphinid and balaenopterid genera (Muizon \& DeVries 1985). The cetacean community at Sacaco, featuring both late Miocene and extant genera, probably represents the initial shift of the coastal faunas towards the ecosystem dynamics of the present-day south-eastern Pacific. The late Miocene and early Pliocene marine conditions found in Sacaco indicate that this was a transitional time for the south-eastern Pacific (DO unpub. data). Warmer conditions typical for the Miocene were still present, as evidenced by global data (Dekens et al. 2007; de Boer et al. 2010), along with typical Humboldt conditions such as the presence of a coastal upwelling (Dunbar et al. 1990; Di Celma et al. 2017; DO unpub. data). These conditions could have promoted the proliferation of a wide array of prey, thus benefiting the heterogeneous cetacean assemblage (DO unpub. data).

Finally, the presence of Kogia danomurai in Sacaco indicates that the modern genus Kogia might have originated in the coastal environments of the south-eastern Pacific; as well as Kogiinae, as evidenced by the presence of the late Miocene Koristocetus (Collareta et al. 2017). The patterning of the facial region of $K$. danomurai indicates that the overall configuration of the forehead organs and soft-tissue structures that are found in extant Kogia were already present, although probably less developed in this fossil species. The derived facial configuration of extant Kogia spp. could mostly reflect their deep-diving foraging habits, in which they are fully dependent on their echolocating system, or (as a result of evolving narrow-band high-frequency biosonar), a means to escape predation by macroraptorial sperm whales (Galatius et al. 2019) and, more recently, killer whales (Morisaka \& Connor 2007).

\section{CONCLUSION}

We have described Kogia danomurai, a new species of pygmy sperm whale (Kogiidae), on the basis of a fragmentary cranium from the uppermost Miocene (5.8$5.7 \mathrm{Ma}$ ) in deposits of the Pisco Formation exposed at the Sacaco locality (southern coast of Peru). Phylogenetic analyses suggest that Kogia danomurai is a sister taxon of the Pliocene Italian species Kogia pusilla and of the clade formed by the extant dwarf and pygmy sperm whales (Kogia breviceps and Kogia sima). As such, it constitutes the oldest known record of the genus Kogia, thus extending its range into the late Miocene. Kogia danomurai is diagnosed on the basis of the following osteological characters: blunt, not transversely compressed antorbital processes; antorbital notch present, but not transformed into a narrow slit; moderately excavated supracranial basin; sagittal crest located medially, but displaced leftwards; and premaxillary fossa located medially, deeper than the rest of the supracranial basin and provided with both a well-defined left wall and a partially developed right one. Our interpretation of the disposition of the facial bony structures indicates that $K$. danomurai and the other fossil kogiids (including the four other extinct species of Kogiinae and Scaphokogiinae that have been described so far from the Pisco Formation), display distinctive arrangement patterns of the bones of the facial region (and, consequently, of the soft-tissue structures as well). Coupled with the different degree of development of several cranial muscles (as highlighted by the attachment sites of the skull), this observation might indicate that these animals evolved different feeding strategies to forage in the shallow water environments of the Peruvian coast during the late Miocene.

Acknowledgements. Our gratitude to G. Billet, C. de Muizon (both MNHN), R. C. Hulbert Jr and C. L. McCaffery (both FLMNH), C. Sorbini (MSNUP), O. Lambert (IRSNB), Daniel Robineau and C. Lefevre (both MNHN), E. Cioppi, L. Bellucci 
and S. Dominici (all MGPUF), G. Insacco (MSNC), G. Manganelli (Dipartimento di Scienze Fisiche, della Terra e dell'Ambiente, Università di Siena, Italy), F. Cancelli (MUSNAF), and D. J. Bohaska, C. W. Potter, and N. D. Pyenson (all USNM), for providing access to the specimens under their care. We extend our gratitude to F. Paolucci (MLP), G. Bianucci (UNIPI), G. Aguirre (PIM-UZH), R. Varas (MUSM), C. de Muizon (MNHN) and O. Lambert (IRSNB) for fruitful discussions on fossil cetaceans, specially sperm whales. We also extend our gratitude to T. Park, E. Fitzgerald, S. Thomas, R. Bennion and one anonymous referee for their constructive comments that further improved the quality of this manuscript. The authors further wish to emphasize their gratefulness to Prof. Dan Omura, to whom this species is dedicated, for his constant support of palaeontology in Peru. We wish to express our gratitude to the Tomatis Korrodi family for donating a skull of Kogia breviceps to the MUSM collection which greatly helped this research. The authors also wish to extend their thanks to Carlos Jaramillo (STRI) and Marcelo R. Sánchez-Villagra (PIM-UZH) for their support while this research project was being executed. This research was supported by funds to AB-P as part of his Ernst Mayr Short-Term Fellowship at STRI, Panama (Smithsonian Tropical Research Institute). Fieldwork was supported by the Peruvian FONDECYT MAGNET program (contract No. 007-2017-UPCH-FONDECYT).

\section{DATA ARCHIVING STATEMENT}

This published work and the nomenclatural act it contains, have been registered in ZooBank: http://zoobank.org/References/817802d2-97c54f71-b77d-0a0f76e908e4. Data for this study are available in the Dryad Digital Repository: https://doi.org/10.5061/dryad.bzkh1896w.

Editor. Stephan Lautenschlager

\section{REFERENCES}

BARNES, L. G. 1973. Praekogia cedrosensis, a new genus and species of fossil pygmy sperm whale from Isla Cedros, Baja California, Mexico. Contributions in Science, Natural History Museum of Los Angeles County, 247, 1-20.

BENITES-PALOMINO, A. and URBINA, M. 2020. La hiperdiversificación de Physeteroidea (Cetacea: Mammalia) del Mioceno tardío en el Pacifico Sur, nuevos fósiles del área de Sacaco, Arequipa, Perú. Revista Peruana de Biología, 27, 261-266.

_ VÉLEZ-JUARBE, J., SALAS-GISMONDI, R. and URBINA, M. 2020a. Scaphokogia totajpe, sp. nov., a new bulky-faced pygmy sperm whale (Kogiidae) from the late Miocene of Peru. Journal of Vertebrate Paleontology, 39, e1728538.

- VElez-JUARBE, J., COllareta, A., OCHOA, D., Altamirano, A. J., CARRÉ, M., LAiME, M. J., URBINA, M. and SALAS-GISMONDI, R. 2020b. Data from: Nasal compartmentalization in Kogiidae (Cetacea, Physeteroidea): insights from a new late Miocene dwarf sperm whale from the Pisco Formation. Dryad Digital Repository. https://doi.org/10.5061/dryad.bzkh1896w
BIANUCCI, G. 1996. I cetaci fossili del Museo di Storia Naturale dell'Universita di Pisa. Atta Della Societa Toscana di Scienze Naturali Memoire Serie A, 103, 63-68.

- SARTI, G., CATANZARITI, R. and SANTINI, U. 1998. Middle pliocene cetaceans from Monte Voltraio (Tuscany, Italy). Biostratigraphical, paleoecological and paleoclimatic observations. Rivista Italiana di Paleontologia $e$ Stratigrafia, 104, 123-130.

- MUIZON, C. DE, URBINA, M. and LAMBERT, O. 2020. Extensive diversity and disparity of the early Miocene Platanistoids (Cetacea, Odontoceti) in the southeastern Pacific (Chilcatay Formation, Peru). Life, 10, 27.

BLAINVILLE, H. M. DE 1838. Sur les cachalots. Annales Francaises et Etrangères D'anatomie et de Physiologie, 2, 335337.

BLOODWORTH, B. E. and ODELL, D. K. 2008. Kogia breviceps (Cetacea: Kogiidae). Mammalian Species, 819, 1-12.

DE BOER, B., VAN DE WAL, R. S. W., BINTANJA, R., LOURENS, L. J. and TUENTER, E. 2010. Cenozoic global ice-volume and temperature simulations with 1-D ice-sheet models forced by benthic $\delta 18 \mathrm{O}$ records. Annals of Glaciology, 51, 23-33.

BOERSMA, A. T. and PYENSON, N. D. 2015. Albicetus oxymycterus, a new generic name and redescription of a basal physeteroid (Mammalia, Cetacea) from the Miocene of California, and the evolution of body size in sperm whales. PLoS One, 10, 1-32.

BRISSON, M.-J. 1762. Regnum animale in classes IX.: Distributum, sive Synopsis methodica. Sistens generalem animalium distributionem in classes IX, \& duarum primarum classium, quadrupedum scilicet \& cetaceorum, particularem divisionem in ordines, sectiones, genera \& species. 296 pp. Theodor Haak, Lugduni Batavorum.

CHEN, I., CHOU, L. S., CHEN, Y. J. and WATSON, A. 2011. The maturation of skulls in postnatal Risso's dolphins (Grampus griseus) from Taiwanese waters. Taiwania, 56, 177-185.

CLARKE, M. R. 1970. Function of the spermaceti organ of the sperm whale. Nature, 228, 873-874.

1978. Structure and proportions of the spermaceti organ in the sperm whale. Journal of the Marine Biological Association of the United Kingdom, 58, 1-17.

2003. Production and control of sound by the small sperm whales, Kogia breviceps and K. sima and their implications for other Cetacea. Journal of the Marine Biological Association of the United Kingdom, 83, 241-263.

COHEN, K. M., HARPER, D. A. T. and GIBBARD, P. L. 2020. ICS international chronostratigraphic chart 2020/03. International Commission on Stratigraphy, IUGS. https://stra tigraphy.org

COllareta, A., LAMBERT, O., MUizon, C. DE, URBINA, M. and BIANUCCI, G. 2017. Koristocetus pescei gen. et sp. nov., a diminutive sperm whale (Cetacea: Odontoceti: Kogiidae) from the late Miocene of Peru. Fossil Record, 20, 259-278.

— CigAla FUlgosi, F. and BiAnUCCI, G. 2019. A new kogiid sperm whale from northern Italy supports psychrospheric conditions in the early Pliocene Mediterranean Sea. Acta Palaeontologica Polonica, 64, 609-626. 
- LAMBERT, O., MUIZON, C. DE, BENITES-PALOMINO, A., URBINA, M. and BIANUCCI, G. 2020. A new physeteroid from the late Miocene of Peru expands the diversity of extinct dwarf and pygmy sperm whales (Cetacea: Odontoceti: Kogiidae). Comptes Rendus Palevol, 19, 79-100.

COOMBS, E. J., ClAvel, J., PARK, T., CHURCHILl, M. and GOSWAMI, A. 2020. Wonky whales: the evolution of cranial asymmetry in cetaceans. BMC Biology, 18, 86.

COZZI, B., HUGGENBERGER, S. and OELSCHLÄGER, H. H. A. 2016. Anatomy of dolphins: Insights into body structure and function. Academic Press, $438 \mathrm{pp}$.

DEKENS, P. S., RAVELO, A. C. and McCARTHY, M. D. 2007. Warm upwelling regions in the Pliocene warm period. Paleoceanography \& Paleoclimatology, 22.

DEVRIES, T. J. 1998. Oligocene deposition and Cenozoic sequence boundaries in the Pisco Basin (Peru). Journal of South American Earth Sciences, 11, 217-231.

- and FRASSINETTI, D. 2003. Range extensions and biogeographic implications of Chilean Neogene mollusks found in Peru. Boletín del Museo Nacional de Historia Natural de Chile, 52, 119-135.

Di Celma, C., MAlinverno, E., BOSiO, G., COLLARETA, A., GARIBOLDI, K., GIONCADA, A., MOLLI, G., BASSO, D., VARAS-MALCA, R. M., PIERANTONI, P. P., VILlA, I. M., LAMBERT, O., LANDINI, W., SARTI, G., CANTALAMESSA, G., URBINA, M. and BIANUCCI, G. 2017. Sequence stratigraphy and paleontology of the Upper Miocene Pisco Formation along the western side of the lower Ica valley (Ica desert, Peru). Rivista Italiana di Paleontologia e Stratigrafia, 123, 255-273.

GARIBOLDI, K., COLlaretA, A., GIONCADA, A., LANDINI, W., PIERANTONi, P. P. and BIANUCCI, G. 2018. Intraformational unconformities as a record of late Miocene eustatic falls of sea level in the Pisco Formation (Southern Peru). Journal of Maps, 14, 607619.

DUNBAR, R. B., MARTY, R. C. and BAKER, P. A. 1990. Cenozoic marine sedimentation in the Sechura and Pisco basins, Peru. Palaeogeography, Palaeoclimatology, Palaeoecology, 77, 235-261.

EHRET, D. J., MacFADDEN, B. J., JONES, D. S., DEVRIES, T. J., FOSTER, D. A. and SALAS-GISMONDI, R. 2012. Origin of the white shark Carcharodon (Lamniformes: Lamnidae) based on recalibration of the Upper Neogene Pisco Formation of Peru. Palaeontology, 55, 1139-1153.

ESPERANTE, R., BRAND, L. R., NICK, K. E., POMA, O. and URBINA, M. 2008. Exceptional occurrence of fossil baleen in shallow marine sediments of the Neogene Pisco Formation, Southern Peru. Palaeogeography, Palaeoclimatology, Palaeoecology, 257, 344-360.

FLOWER, W. H. 1867. IV. Description of the skeleton of Inia geoffrensis and of the skull of Pontoporia blainvillii, with remarks on the systematic position of these animals in the order Cetacea. Transactions of the Zoological Society of London, 6, 87-116.

Galatius, A., Olsen, M. T., SteEman, M. E., RACICOT, R. A., BRADSHAW, C. D., KYHN, L. A. and MILLER, L. A. 2019. Raising your voice: evolution of narrow-band high-frequency signals in toothed whales (Odontoceti). Biological Journal of the Linnean Society, 126, 213-224.

GEISLER, J. H., McGOWEN, M. R., YANG, G. and GATESY, J. 2011. A supermatrix analysis of genomic, morphological, and paleontological data from crown Cetacea. BMC Evolutionary Biology, 11 (112), 33.

GILL, T. 1871. The sperm whales, giant and pygmy. The American Naturalist, 4, 725-743.

GIONCADA, A., COLlARETA, A., GARIBOLDI, K., LAMBERT, O., DI CELMA, C., BONACCORSI, E., URBINA, M. and BIANUCCI, G. 2016. Inside baleen: exceptional microstructure preservation in a late Miocene whale skeleton from Peru. Geology, 44, 839-842.

GOLOBOFF, P. A. 1993. Estimating character weights during tree search. Cladistics, 9, 83-91.

GOOLD, J. C. and CLARKE, M. R. 2000. Sound velocity in the head of the dwarf sperm whale, Kogia sima, with anatomi$\mathrm{cal}$ and functional discussion. Journal of the Marine Biological Association of the United Kingdom, 80, 535-542.

GRAY, J. E. 1821. On the natural arrangement of vertebrate mammals. London Medical Repository, 15, 296-310.

- 1846. On the cetaceous animals. 13-53. The Zoology of the Voyage of H.M.S. Erebus \& Therror, Under the Command of Captain Sir James Clark Ross, R.N., F.R.S., During the Years 1839 to 1843 , Vol. 1.

HOCKING, D. P., MARX, F. G., PARK, T., FITZGERALD, E. M. G. and EVANS, A. R. 2017. A behavioural framework for the evolution of feeding in predatory aquatic mammals. Proceedings of the Royal Society B, 284, e20162750.

- BIANUCCI, G. and MUIZON, C. DE 2008. A new stem-sperm whale (Cetacea, Odontoceti, Physeteroidea) from the Latest Miocene of Peru. Comptes Rendus Palevol, 7, 361369.

— POST, K., MUIZON, C. DE, SALAS-GISMONDI, R., URBINA, M. and REUMER, J. 2010. The giant bite of a new raptorial sperm whale from the Miocene epoch of Peru. Nature, 466, 105-108.

- and BEATTY, B. L. 2014. Bony outgrowths on the jaws of an extinct sperm whale support macroraptorial feeding in several stem physeteroids. Naturwissenschaften, 101, 517521.

- Collareta, A., LANDini, W., POST, K., RAMASSAMY, B., DI CELMA, C., URBINA, M. and BIANUCCI, G. 2015. No deep diving: evidence of predation on epipelagic fish for a stem beaked whale from the late Miocene of Peru. Proceedings of the Royal Society B, 282, e20151530.

- BIANUCCI, G. and MUIZON, C. DE 2016. Macroraptorial sperm whales (Cetacea, Odontoceti, Physeteroidea) from the Miocene of Peru. Zoological Journal of the Linnean Society published online 7 September. https://doi.org/10.1111/zoj. 12456

- MUIZON, C. DE, URBINA, M. and BIANUCCI, G. 2020. A new longirostrine sperm whale (Cetacea, Physeteroidea) from the lower Miocene of the Pisco Basin (southern coast of Peru). Journal of Systematic Palaeontology, 18, $1707-1742$. 
LINNAEUS, C. 1758. Systema Naturae, 10th edn, vol. 1. Laurentius Salvius, Holmiae, 824 pp.

MADDISON, W. P. and MADDISON, D. R. 2011. Mesquite: a modular system for evolutionary analysis. v. 2.75. http://mesquiteproject.org

MAROCCO, R. and MUIZON, C. DE 1988. Le Bassin Pisco, bassin cénozoïque d ' avant arc de la côte du Pérou central : analyse géodynamique de son remplissage. Géodynamique, 3, 3-19.

MATSUMOTO, H. 1926. On some fossil cetaceans of Japan. Science Reports of the Tohoku Imperial University, Sendai, Japan, Second Series (Geology), 10, 17-27.

McGOWEN, M. R., SPAULDING, M. and GATESY, J. 2009. Divergence date estimation and a comprehensive molecular tree of extant cetaceans. Molecular Phylogenetics \& Evolution, 53, 891-906.

_ TSAGKOGEOrGA, G., ÁlvAREZ-CARretero, S., DOS REIS, M., STRUEBIG, M., DEAVILle, R., JEPSON, P. D., JARMAN, S., POLANOWSKI, A., MORIN, P. A. and ROSSITER, S. J. 2019. Phylogenomic resolution of the cetacean tree of life using target sequence capture. Systematic Biology, 69, 479-501.

MEAD, J. G. and FORDYCE, R. E. 2009. The therian skull: a lexicon with emphasis on the odontocetes. Smithsonian Contributions to Zoology, 1-249.

MORISAKA, T. and CONNOR, R. C. 2007. Predation by killer whales (Orcinus orca) and the evolution of whistle loss and narrow-band high frequency clicks in odontocetes. Journal of Evolutionary Biology, 20, 1439-1458.

MUIZON, C. DE 1984. Les vertébrés fossiles de la Formation Pisco (Pérou). II: Les Odontocètes (Cetacea, Mammalia) du Pliocène inférieur de Sud-Sacaco. Institute Francais d'Etudes Andines Editions Recherche sur les Civilisations Mémoire, 50, $188 \mathrm{pp}$.

— 1988. Les vertébrés fossiles de la Formation Pisco (Perou). Troisième partie: les odontocètes (Cetacea, Mammalia) $d u$ Miocène. Institute Francais d'Etudes Andines Editions Recherche sur les Civilisations. Mémoire, 78, 244 pp.

MUIZON, C. DE and BELLON, H. 1980. L'âge mio-pliocène de la Formation Pisco (Pérou). Comptes Rendus Hebdomadaires des Séances de L'Académie des Sciences de Paris, 290, 1063-1066.

— and DEVRIES, T. J. 1985. Geology and paleontology of late Cenozoic marine deposits in the Sacaco area (Peru). Geologische Rundschau, 74, 547-563.

NORRIS, K. S. and HARVEY, G. W. 1972. A theory for the function of the spermaceti organ of the sperm whale (Physeter catodon L.). 397-417. In GALLER, S. R., SCHMIDTKOENIG, K., JACOBS, G. J. and BELLEVILLE, R. E. (eds) NASA Special Publication 262, Animal orientation and navigation. NASA, Washington DC.
OWEN, R. 1866. On some Indian Cetacea collected by Walter Elliot, Esq. Transactions of the Zoological Society of London, $\mathbf{6}$, $17-47$.

PAOLUCCI, F., BUONO, M. R., FERNÁNDEZ, M. S., MARX, F. G. and CUITIÑN, J. I. 2020. Diaphorocetus poucheti (Cetacea, Odontoceti, Physeteroidea) from Patagonia, Argentina: one of the earliest sperm whales. Journal of Systematic Palaeontology, 18, 335-355.

PILLERI, G. 1987. The Cetacea of the Italian Pliocene with a descriptive catalogue of the specimens in the Florence Museum of Palaeontology. Brain Anatomy Institute, Berne, 160 pp.

PYENSON, N. D. and SPONBERG, S. N. 2011. Reconstructing body size in extinct crown Cetacea (Neoceti) using allometry, phylogenetic methods and tests from the fossil record. Journal of Mammalian Evolution, 18, 269-288.

SCHULTE, H. VON 1917. The skull of Kogia breviceps Blainv. Bulletin of the American Museum of Natural History, 37, 361-404.

— and FOREST SMITH, M. DE 1918. The external characters, skeletal muscles, and peripheral nerves of Kogia breviceps (Blainville). Bulletin of the American Museum of Natural History, 38 (2), 7-72.

SONG, Z., XU, X., DONG, J., XING, L., ZHANG, M., LIU, X., ZHANG, Y., LI, S. and BERGGREN, P. 2015. Acoustic property reconstruction of a pygmy sperm whale (Kogia breviceps) forehead based on computed tomography imaging. The Journal of the Acoustical Society of America, 138, 3129-3137.

SWOFFORD, D. L. 2002. PAUP*: phylogenetic analysis using parsimony. Version 4.0b10. Sinauer Associates, Sunderland, Massachusetts.

THORNTON, S. W., McLELlAN, W. A., ROMMEL, S. A., DillamAN, R. M., NOWACEK, D. P., KOOPMAN, H. N. and ANN PABST, D. 2015. Morphology of the nasal apparatus in pygmy (Kogia Breviceps) and dwarf (K. Sima) sperm whales. Anatomical Record, 298, 1301-1326.

VELEZ-JUARBE, J., WOOD, A. R., DE GRACIA, C. and HENDY, A. J. W. 2015. Evolutionary patterns among living and fossil kogiid sperm whales: evidence from the Neogene of Central America. PLoS One, 10, 1-29.

VÉLEZ-JUARBE, J., WOOD, A. R. and PIMIENTO, C. 2016. Pygmy sperm whales (Odontoceti, Kogiidae) from the Pliocene of Florida and North Carolina. Journal of Vertebrate Paleontology, 36, e1135806.

WERTH, A. J. 2006. Mandibular and dental variation and the evolution of suction feeding in Odontoceti. Journal of Mammalogy, 87, 579-588.

WhitMore, F. C. and KALTENBACH, J. A. 2008. Neogene Cetacea of the Lee Creek Phosphate Mine, North Carolina. Virginia Museum of Natural History Special Publication, 14, 181-269. 